\title{
Structural relationships between Helminthoid Flysch and Briançonnais Units in the Marguareis Massif: A key for deciphering the finite strain pattern in the external southwestern Alps
}

\author{
Edoardo Sanità $^{1,2}$ (1) | Jean Marc Lardeaux ${ }^{3}$ | Michele Marroni ${ }^{1,4}$ | Guido Gosso ${ }^{5}$ | \\ Luca Pandolfi ${ }^{1,4}$
}

${ }^{1}$ Dipartimento di Scienze della Terra, Università di Pisa, Pisa, Italy

${ }^{2}$ Dipartimento di Scienze della Terra, Università di Firenze, Florence, Italy

${ }^{3}$ Géosciences Azur, UMR CNRS Université de Nice-Sophia Antipolis, Nice, France

${ }^{4}$ Istituto di Geoscienze e Georisorse, CNR, Via Moruzzi 1, Pisa, Italy

${ }^{5}$ Dipartimento di Scienze della Terra, Università di Milano, Milan, Italy

\section{Correspondence}

Edoardo Sanità, Dipartimento di Scienze della Terra, Università di Pisa, Via Santa Maria 53, 56126 Pisa, Italy.

Email: edoardo.sanita@unifi.it

Handling Editor: C. Frassi
The structural setting and tectonic evolution of the Marguareis Massif (located at the boundary between the Maritime and Ligurian Alps) has long been matter of debate. After new meso- and micro-structural studies and field investigations, the tectonic unit interplay outlines a finite structural architecture more complex than that proposed in previous interpretations. We depict a stack of Briançonnais Units stemming from the Europe continental margin, and the Helminthoid Flysch Unit, detached from its original basement whose original palaeogeographic domain is still a matter of debate. Our results highlight for the first time that each unit recorded different prestacking folding events progressively developed at different structural levels. The events occurred during the stacking of the units produced shear zones with top-toSW sense of movement. After the syn-stacking tectonics achieved during the Late Eocene-Early Oligocene collisional events, the whole stack recorded the same poststacking deformation history here represented by a fold system with sub-horizontal axial planes and faults. Similar tectonic evolution was documented in other sectors of the Western Alps by previous authors.

\section{KEYWORDS}

Briançonnais Domain, Helminthoid Flysch Unit, deformation history, lithostratigraphy, Marguareis Massif

\section{1 | INTRODUCTION}

The Alpine collisional belt is the result of a long-lived, convergencerelated geodynamic history that started in the Late Cretaceous with the subduction of the oceanic lithosphere of the Ligure-Piemontese Ocean. The closure of the Ligure-Piemontese Ocean led to continental collision between the Europe and the Adria margins in the Late Eocene-Early Oligocene, and then in the Late Oligocene to Neogene development of a doubly-verging crustal belt (Coward \& Dietrich, 1989; Dal Piaz, Bistacchi, \& Massironi, 2003; Handy, Schmid, Bousquet, Kissling, \&
Bernoulli, 2010; Rosenbaum, Lister, \& Duboz, 2002; Stampfli, Borel, Cavazza, Mosar, \& Ziegler, 2001). The result of this geodynamic history is a curved collisional belt, where a stack of continental and oceanic nappes, with deformations and metamorphic imprints acquired at different depth and in different times, are well exposed. In Western and Central Alps, geometry, timing and kinematics of nappes stacking is nowadays relatively well established (Butler, Matthews, \& Parish, 1986; Choukroune et al., 1986; Gidon, 1972; Gratier, Mènard, \& Arpin, 1989; Handy et al., 2010; Merle \& Brun, 1984; Roure, Howell, Guellec, \& Casero, 1990; Pfiffner, Erard, \& Stauble, 1997; Schmid \& Kissling, 2000; 


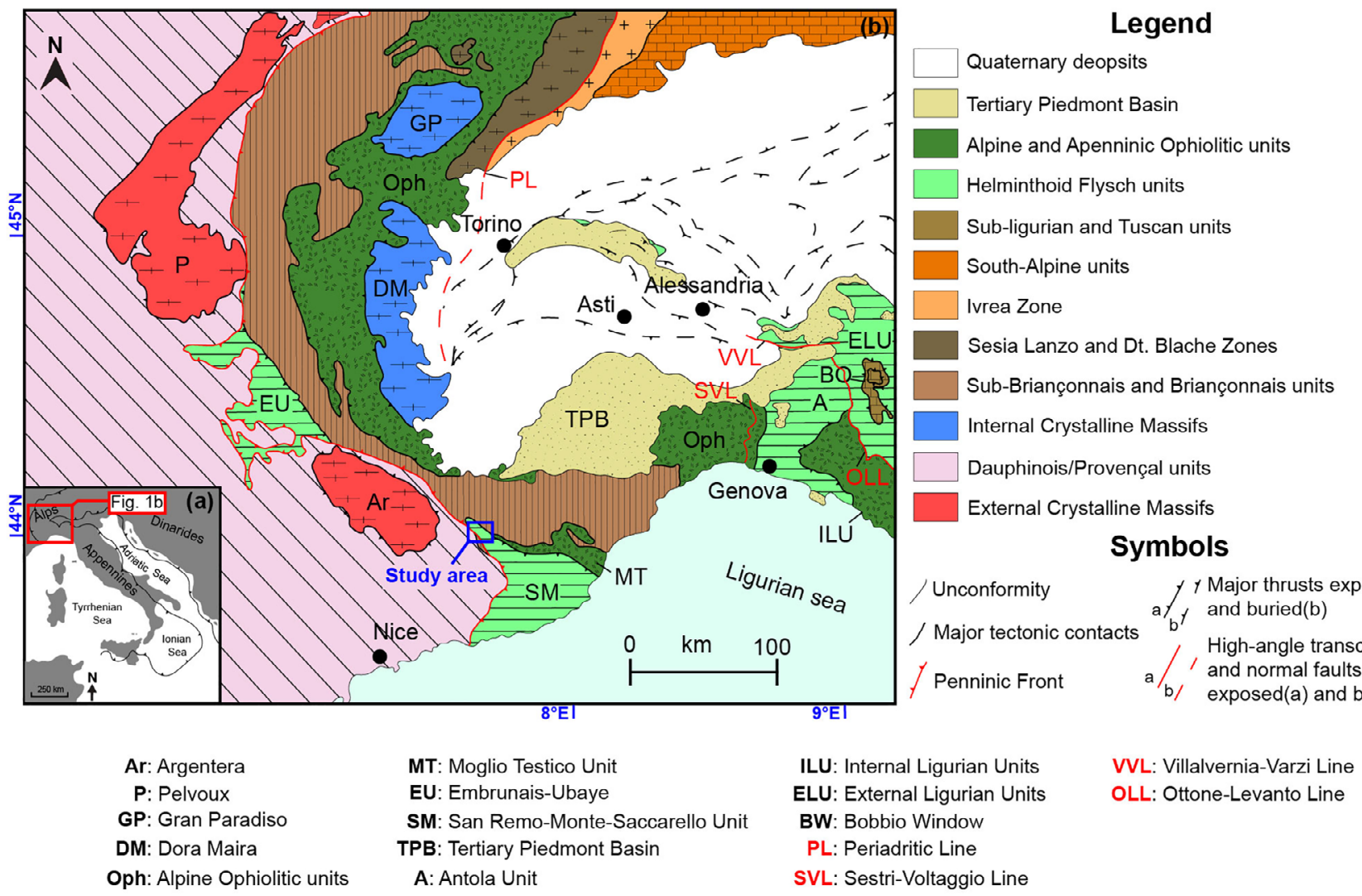

FIGURE 1 (a) Location of map in 1b. (b) Tectonic sketch map of the Western Alps-Northern Apennines (modified by Molli et al., 2010, Barbero, Festa, Saccani, Catanzariti, \& D'Onofrio, 2019). The blue box indicates the study area [Colour figure can be viewed at wileyonlinelibrary.com]

Tardy et al., 1990; Tricart, 1984; Tricart, Schwartz, Sue, Poupeau, \& Lardeaux, 2001; Tricart, Schwartz, Sue, \& Lardeaux, 2004). However, the tectonic history of several key-areas of the Western Alps is still poorly understood, making necessary further detailed studies for all the steps in the history of this belt.

One of these areas is located at the boundary between the Maritime and Ligurian Alps, in the southwestern termination of the Western Alps (Figure 1a,b). In this area, despite the available scientific contributions (e.g., Bertok, Musso, d'Atri, Martire, \& Piana, 2018; Brizio et al., 1983; d'Atri, Piana, Barale, Bertok, \& Martire, 2016; Lanteaume, 1968; Maino \& Seno, 2016; Mueller, Maino, \& Seno, 2020; Piana et al., 2009; Vanossi, 1972), the geometry and structural evolution of nappes stacking, remains a matter of debate. Facing these contradictions and improving the understanding of finite strain pattern and tectonic evolution of this sector of the Alpine collisional belt, requires reliable stratigraphic and structural constraints.

The goal of this article is therefore to highlight the complex tectonic evolution of the units located in the southwestern sector of the Marguareis Massif (boundary between Maritime and Ligurian Alps), a key area for the comprehension of Alpine orogeny. In this area, the units show different deformation histories experienced at different structural levels. To reach this goal, we performed a detailed field survey and meso- to micro-scale structural analysis in the southwestern sector of the Marguareis Massif. Finally, a comparison between our results with other key-sectors of the Western Alps is also discussed.

\section{2 | GEOLOGICAL FRAMEWORK OF THE MARITIME ALPS}

Geophysical investigations in the Western Alps indicate that this collisional belt is characterized by a doubly-verging crustal-scale architecture. The westernmost edge of this belt (Figure 1b) consists of a foldand-thrust belt represented by Dauphinois/Provençal Units and the External Crystalline Massifs (Figure 1b), both pertaining to the former continental margin of the Europe Plate. This fold-and-thrust belt is overlain eastward by Sub-Briançonnais and Briançonnais units by the Penninic Front (Figure 1b), an east-dipping thrust zone developed since the Early Oligocene (e.g., Barfety et al., 1996; Ford, Duchêne, Gasquet, \& Vanderhaeghe, 2006; Ford, Lickorish, \& Kusznir, 1999; Gosso et al., 2019; Lanteaume, 1968; Maino et al., 2015; Maino \& Seno, 2016; Malaroda, 1970; Seno, Dallagiovanna, \& Vanossi, 2005). These units, together with the Internal Crystalline Massifs (Figure 1b), are regarded as the remnants of the thinned continental margin of the Europe Plate (Decarlis, Dallagiovanna, Lualdi, Maino, \& Seno, 2013 and quoted references; Vanossi, 1972; Vanossi et al., 1984) and are 
tectonically overlain by the oceanic-derived units (Ophiolitic units in Figure 1b) representative of Ligure-Piemontese Ocean (Béthoux et al., 2007; Lardeaux et al., 2006; Paul et al., 2001; Schreiber, Lardeaux, Martelet, Courrioux, \& Guillen, 2010). Some authors (e.g., Frisch, 1979; Schmid, Fügenschuh, Kissling, \& Schuster, 2004; Stampfli, 1993) proposed that the Briançonnais Units represent a block of continental crust separated by the Europe Plate in the Early Cretaceous time, forming the so-called Briançonnais micro-continent. Wortmann, Weissert, Funk, and Hauck (2001) considered the Briançonnais Domain to be part of the Europe Plate until the end of Jurassic. In according with Lavier and Manatschal (2006), Mohn, Manatschal, Müntener, Beltrando, and Masini (2010) proposed that the Briançonnais Domain represented a portion of continental crust, located in between the Europe Plate and Adria Plate, formed during the Jurassic rifting.

The study area is located in the southwestern side of the Western Alps (Figure 1b), at the boundary between the Maritime and Ligurian Alps. In this area, the Dauphinois/Provençal Domain consists of preAlpine basement rocks reworked during Alpine collision (ArgenteraMercantour, External Crystalline Massifs) recording Variscan tectonics (Corsini, Ruffet, \& Caby, 2004; Sanchez et al., 2010; Sanchez, Rolland, Jolivet, \& Brichau, 2011). This basement rocks are associated with slices of Meso-Cenozoic sedimentary covers showing polyphase deformation history associated to very low-grade metamorphism (Bersezio, Barbieri, \& Mozzi, 2002). In turn, the Briançonnais Units consists of Meso-Cenozoic metasedimentary cover whose pristine basement is represented by the Internal Crystalline Massifs, mainly consisting in pre-Alpine basement rocks (e.g., Bucher \& Bousquet, 2007; Compagnoni, Elter, \& Lombardo, 1974; Le Bayon \& Ballèvre, 2004; Malusà, Mosca, Borghi, Dela Pierre, \& Polino, 2002; Michard, Avigad, Goffé, \& Chopin, 2004). The Internal Crystalline Massifs as well as the Briançonnais Units are affected by a polyphase deformation history associated with HP-LT metamorphism (e.g., Bertrand, Paquette, \& Guillot, 2005; Bousquet et al., 2008 and reference therein). This polyphase deformation history is achieved during the significant NE-SW shortening resulting from the continental collision processes (Carminati, 2001; Carminati \& Gosso, 2000; Fallot, 1949; Gèze, Lanteaume, Peyre, \& Vernet, 1968; Goguel, 1936; Gosso et al., 2019; Maino et al., 2015; Siddans, 1979; Vanossi \& Gosso, 1983). The Sub-Briançonnais Units are considered as derived from the domain representing the transition between Briançonnais and Dauphinois/Provençal domains. It consists of Meso-Cenozoic sedimentary covers detached from their original basement (Debelmas \& Kerckhove, 1980; Gidon, 1972). At the boundary between the Maritime and Ligurian Alps, the Briançonnais, SubBriançonnais and Dauphinois/Provençal Units are tectonically overlain by the non-metamorphic Helminthoid Flysch Unit (e.g., San RemoMonte Saccarello Unit; Figure 1b). This unit includes a Late Cretaceous sedimentary succession detached from its original basement whose palaeogeographic origin is still a matter of debate (e.g., Kerckhove, 1969; Lanteaume, 1968; Maino et al., 2015; Maino \& Seno, 2016; Mueller, Langone, Patacci, \& Di Giulio, 2018; Sagri, 1984).

\section{3 | GEOLOGY OF THE MARGUAREIS MASSIF: STATE-OF-THE-ART}

In the Marguareis Massif, a robust stratigraphic database, necessary for any structural analysis, was the scope of earliest modern researchers over a long time. Vanossi (1972) improved significantly the detailed chronoand lithostratigraphic description proposed by previous authors (e.g., Bloch, 1958; Campredon, 1977; Guillaume, 1965; Lanteaume, 1968). Based on data of Bloch (1958), Lanteaume (1968) and Vanossi (1972), Brizio et al. (1983) added a structural analysis in the western sectors of the Marguareis Massif, and recognized two tectonic units: the Marguareis Unit (cf. Monte Marguareis Unit of Vanossi, 1972) showing a typical succession of the Briançonnais Units (Ligurian-Briançonnais Units of Vanossi, 1972), here characterized by Triassic-Jurassic platform to Cretaceous hemipelagic carbonate deposits to Eocene deep-sea fan siliciclastic turbidite, and the Helminthoid Flysch Unit consisting of deepsea siliciclastic turbidite with its basal complex (basal complexes of Lanteaume, 1957). According with Lanteaume (1962), a tectonic unit, known as Lambeaux de Charriage (cf. Tectono-stratigraphic complex of Brizio et al., 1983), has been recognized by several authors as lying under the Helminthoid Flysch Unit. The Lambeaux de Charriage is made of siliciclastic turbidite deposits with huge blocks with Briançonnais affinity (according with Lanteaume, 1962) but their stratigraphy and palaeogeographic origin are unclear. Brizio et al. (1983) suggest a structural evolution in which the lower part of the basal complex and Marguareis Unit share the same polyphase deformation history, the latter characterized by three folding events developed from micro- to map-scale. In contrast, the Helminthoid Flysch Unit and the uppermost part of its basal complex show a less complex deformation history characterized by one folding event (Brizio et al., 1983).

Recently, Piana et al. (2009) described in the Marguareis Massif a high-angle strike-slip to normal fault-boundary between the Europederived continental units (Briançonnais and Dauphinois/Provençal units) and San Remo-Monte Saccarello Unit (cf. Helminthoid Flysch Unit of Brizio et al., 1983), which previously over-thrust the continental units. The fault network separates tectonic units that record different P-T conditions from anchizonal to lower greenschist facies (Piana, Battaglia, \& Bertok, 2014). This interpretation was subsequently developed by d'Atri et al. (2016) who proposed that the fault network affecting the Marguareis Massif is a part of an E-W-oriented shear zone active during Alpine collision. According with these authors, this shear zone played a key-role in the finite architecture in this sector of the southwestern Alps.

\section{4 | METHODS}

We updated the structural history of the studied tectonostratigraphic units, by fieldwork aimed to trace in the map the mineral-scale foliation trajectories (not reported in the geological map of Figure 2a) to define the related meso-, megascopic folding systems and to feature the thrust surfaces. Mesoscopic fabric element orientations are displayed in the cross-section of Figure $2 c$ related to the new 1:10,000 


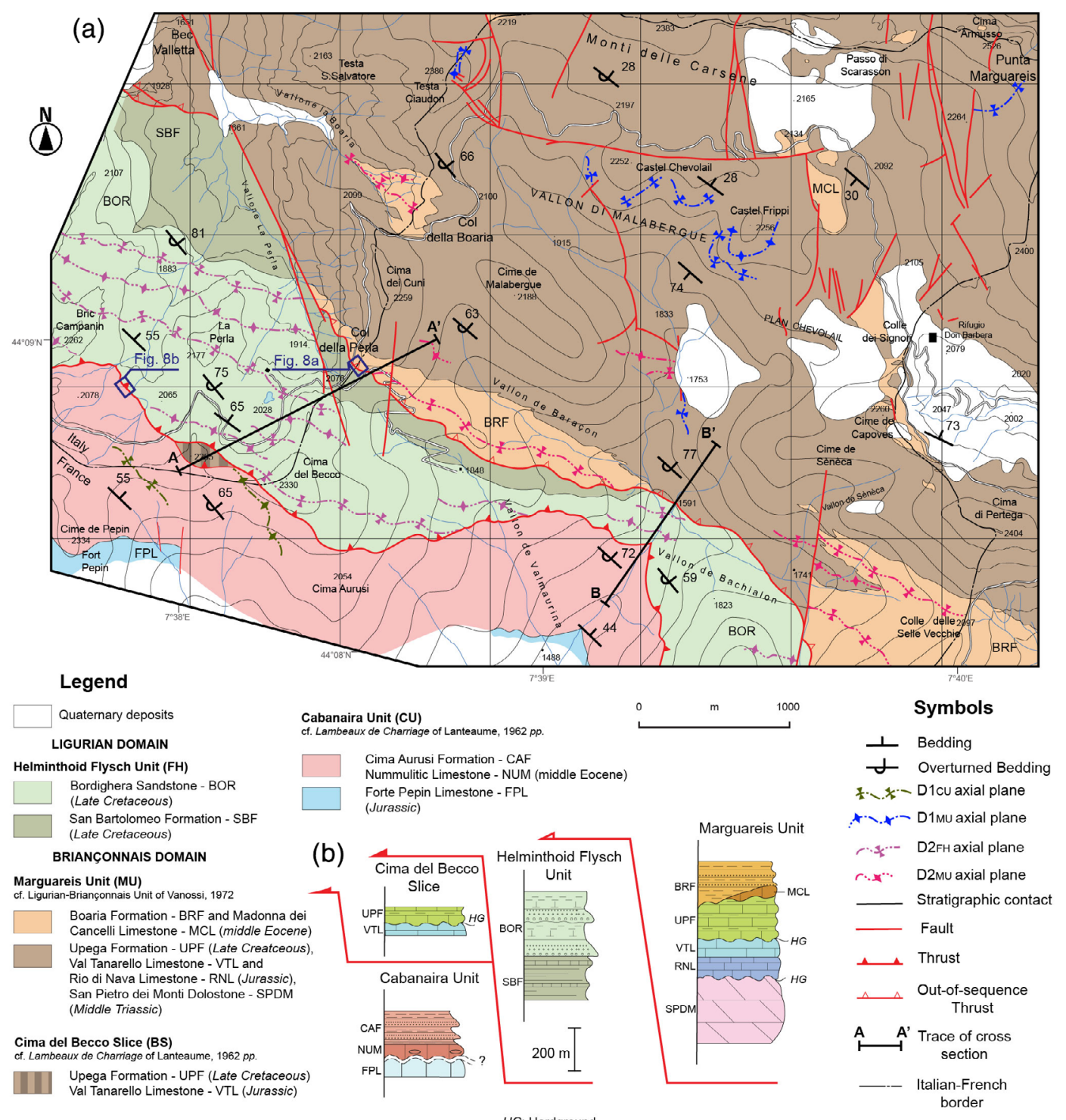

(c) SW

HG. Hardground

NE

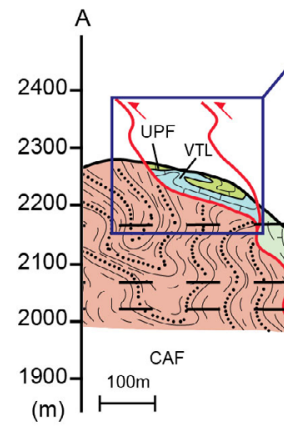

Fig. 8c, d

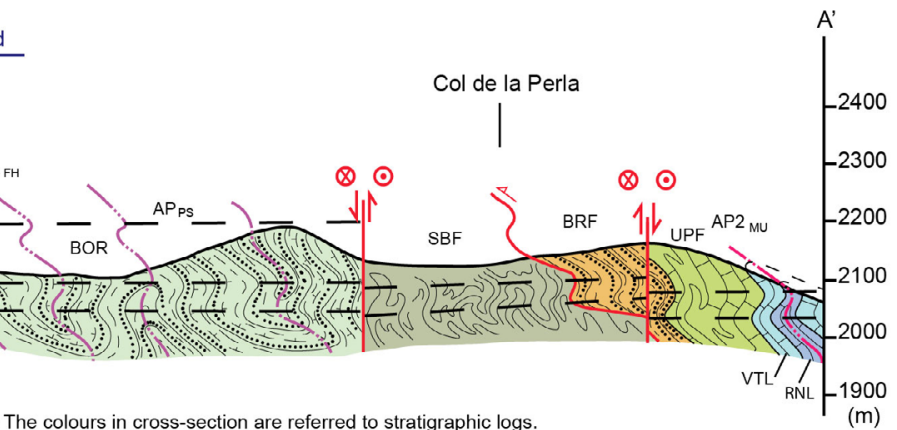

FIGURE 2 (a) Geological map of the study area (blue box in 1b). (b) Stratigraphic logs of the tectonostratigraphic units. (c) Geological crosssection related to A-A' trace in (a). BRF: Boaria Formation; MCL: Madonna dei Cancelli Limestone; UPF: Upega Formation; VTL: Val Tanarello Limestone; RNL: Rio di Nava Limestone; SPDM: San Pietro dei Monti Dolostone; BOR: Bordighera Sandstone; SBF: San Bartolomeo Formation; CAF: Cima Aurusi Formation; NUM: Nummulitic Limestone; FPL: Forte Pepin Limestone; $\mathrm{AP} 2_{\mathrm{MU}}$ : axial plane of the $\mathrm{F} 2_{\mathrm{MU}}$ folds; $\mathrm{AP} 2_{\mathrm{FH}}$ : $\mathrm{axial}_{\mathrm{plane}}$ of the $\mathrm{F} 2_{\mathrm{FH}}$ folds; $\mathrm{AP}_{\mathrm{PS}}$ : axial plane of post-stacking folds [Colour figure can be viewed at wileyonlinelibrary.com]

geological map of Figure 2a, and their spatial relationships are showed in the stereo plots of Figure 6. This dataset refines and re-interprets the relative chronology proposed by Brizio et al. (1983) for the northeastern sector of our study. Samples of foliations of different relative ages in lithotypes with similar rheology were collected for optical microstructural analysis in several key areas, where clear overprinting 
relationships between two or more structures are found (i.e., along limbs and hinge zones). The clear meso- to micro-scale overprinting relations between different structures and their spatial relationships are the adopted criteria to distinguish the different deformation phases recorded by each unit. This approach allowed the comparison the deformation patterns of each unit (Section 6.1) with the ones postdating the tectonic stacking (Section 6.3). Since Cima del Becco Slice shows deformation events corresponding to those documented in Marguareis Unit, for its structural features the readers can be referred to Section 6.1.2.

\section{5 | LITHOSTRATIGRAPHY}

In the study area (Figure 2a) during a recent geological survey, we documented, for the first time, a complex stack of tectonostratigraphic units (Figure 2a-c). They are, from the structurally highest to the lowest (Figure 2a,b): the Marguareis Unit (MU, Brizio et al., 1983) that consists of a typical sedimentary succession of the Briançonnais Domain (cf. Ligurian-Briançonnais Domain of Vanossi, 1972); the Helminthoid Flysch Unit (FH) stemming from Ligurian Domain; a decametric-sized tectonic slice (here called Cima del Becco Slice, cf. Lambeaux de Charriage of Lanteaume, 1962) stemming from Briançonnais Domain, and the Cabanaira Unit (CU, cf. Lambeaux de Charriage of Lanteaume, 1962) showing a sedimentary succession similar to that of the Briançonnais Domain. A short description of the lithostratigraphic features of each unit is provided hereafter. Owing the correlation between the Cima del Becco Slice and the Marguareis Unit (Figure 2b), the lithostratigraphic features of both are discussed together in the Section 5.2.

\subsection{Helminthoid Flysch Unit}

The Helminthoid Flysch Unit consists of a Late Cretaceous nonmetamorphic sedimentary succession detached from its original basement. It shows a NW-SE trend and extends for about $7 \mathrm{~km}^{2}$ (Figure 2a).
The oldest formation of this unit is represented by San Bartolomeo Formation (Figure 2b, basal complexes of Lanteaume, 1957) consisting of varicoloured manganesiferous shales (Figure $3 a$ ) and rare $\mathrm{cm}$-thick beds of fine-grained limestones interpreted as deposits sedimented in a basin plain environment (Sagri, 1984). According to Manivit and Prud'Homme (1990) and Cobianchi, Di Giulio, Galbiati, and Mosna (1991), this formation can be referred to Hauterivian-Campanian time.

The San Bartolomeo Formation grades upward to the Bordighera Sandstone (Figure 2b). The latter consists of Late Cretaceous siliciclastic turbidites capped by thick marls and dark shales (Figure 3b) with an $a / p$ ratio $>1$. Coarse- to medium-grained arenitic beds are characterized by high erosive ability testified by centimetre-thick clay chips, amalgamation surfaces and erosional base (F5 facies of Mutti, 1992). According to Manivit and Prud'Homme (1990) and Cobianchi et al. (1991), the depositional environments is related to inner deep-sea fan. The calcareous nannofossils association found in the Bordighera Sandstone indicate an age not older than Coniacian (Campanian?) (Manivit \& Prud'Homme, 1990).

\section{2 | Marguareis Unit}

This unit covers the greater part of the study area and extends over about $15 \mathrm{~km}^{2}$ (Figure 2a). It consists of Middle Triassic peri-tidal carbonates (Figure 4a, San Pietro dei Monti Dolostone - Vanossi, 1969). A Late Triassic-Middle Jurassic hiatus separates Triassic deposits from overlying Middle Jurassic platform deposits and nodular pelagic limestones (Figure 4b, Rio di Nava and Val Tanarello Limestone respectively - Boni, Cerro, Gianotti, \& Vanossi, 1971; cf. Marbres de Guillestre of Fallot \& Faure-Muret, 1954). A mineralized hardground with stromatolites marks the Early to Late Cretaceous stratigraphic hiatus between the Jurassic carbonates and the overlying hemipelagic deposits (marly limestones) of the Upega Formation (Figure 4c) of Late Cretaceous age (Calcschistes Planctoniques of Fallot \& Faure-Muret, 1954).

The top of the succession is represented by middle(?) Eocene Nummulitic limestone (Figure 4d, Madonna dei Cancelli Limestone of Vanossi, 1972), and deep-sea fan siliciclastic turbidites (Figure 4e,
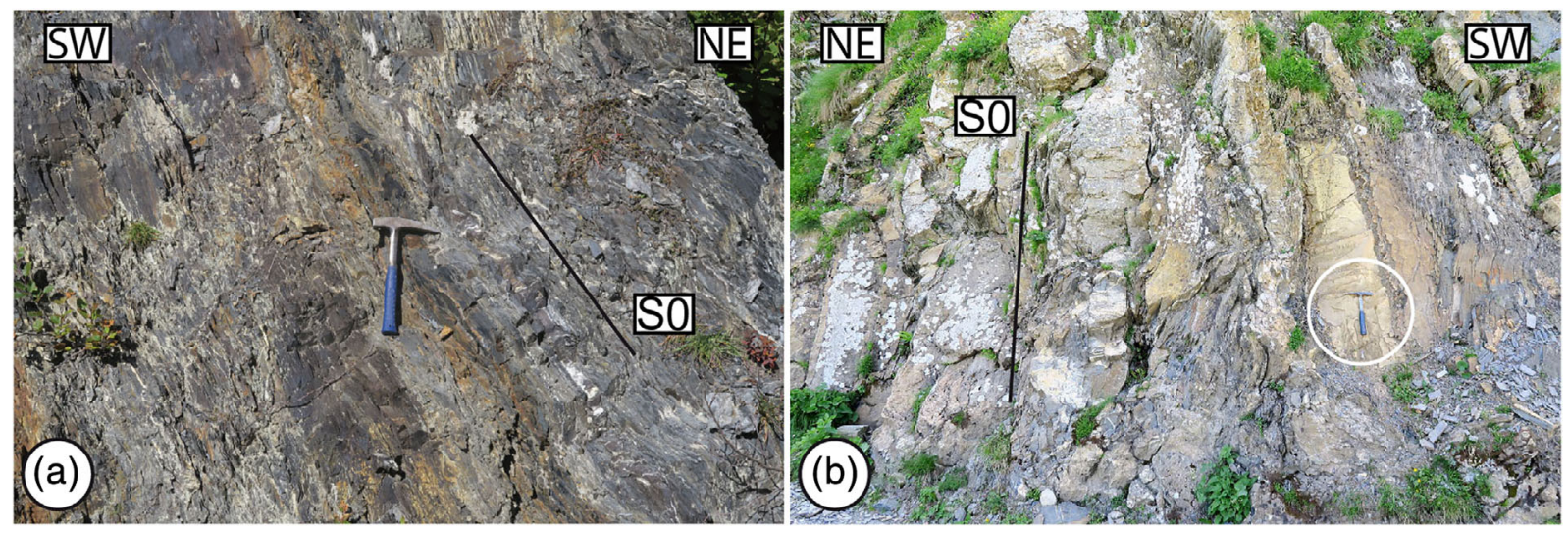

FIGURE 3 (a) San Bartolomeo Formation in the Col della Perla area. (b) Bordighera Sandstone near to La Perla area. The white circle indicates the hammer (length: $33 \mathrm{~cm}$ ). So: bedding [Colour figure can be viewed at wileyonlinelibrary.com] 

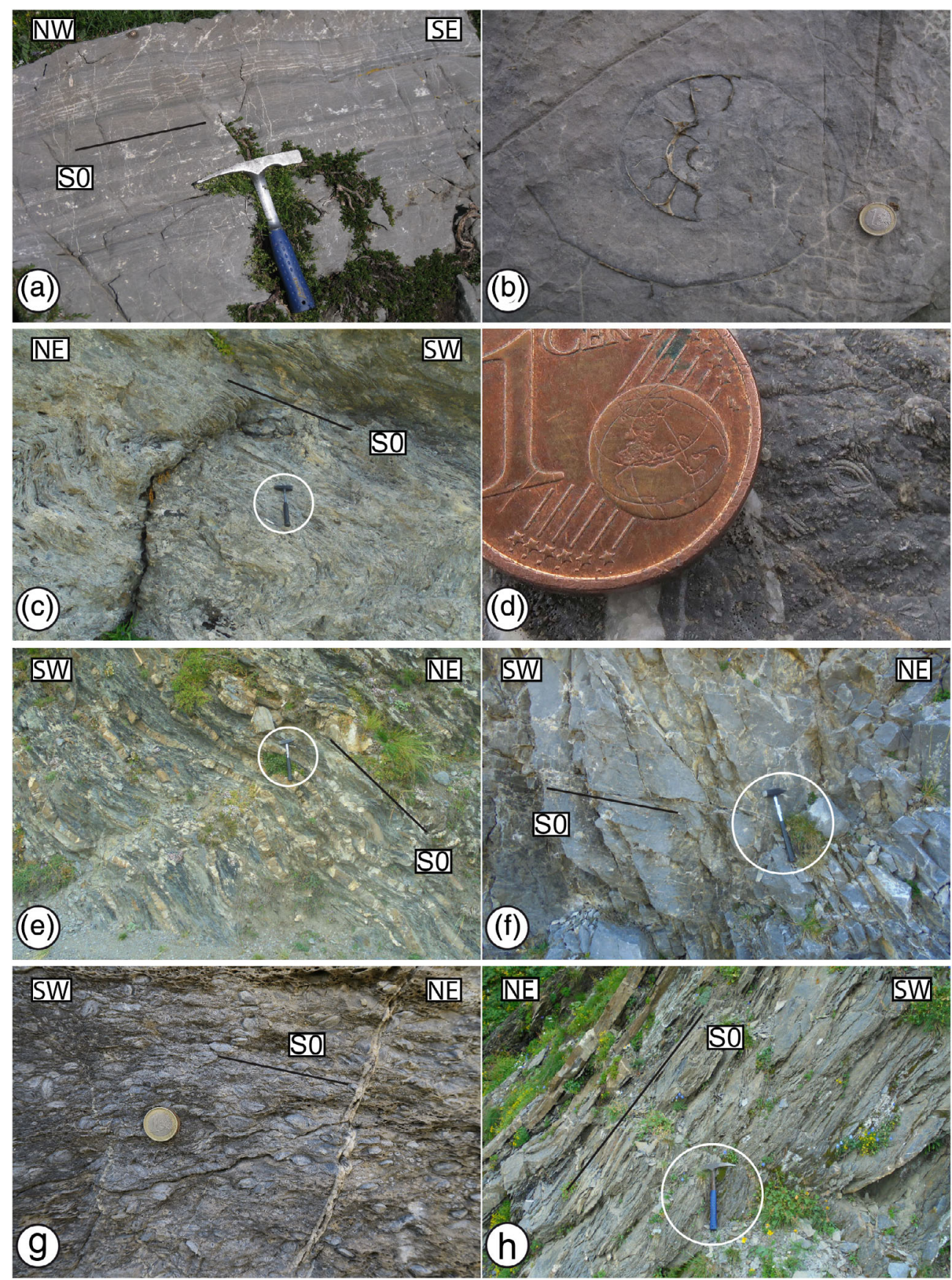

FIGURE 4 (a) San Pietro dei Monti Dolostone near to Rifugio Don Barbera. (b) Rio di Nava Limestone in Castel Frippi area. (c) Upega Formation at Colle dei Signori area. (d) Madonna dei Cancelli Limestone located to the East of Cime de Capoves.

(e) Boaria Formation at Colle delle Selle Vecchie area. (f) Forte Pepin Limestone to the South of Cime de Pepin. (g) Nummulitic Limestone to the North of Cime de Pepin. (h) Cima Aurusi Formation at Vallon de Valmaurina area. The white circles indicate the hammer (length: $33 \mathrm{~cm}$ ). S0: bedding [Colour figure can be viewed at wileyonlinelibrary.com]
Boaria Formation; cf. Flysch Noir of Lanteaume, 1968). The latter deposits unconformably overlie both Upega Formation and Madonna dei Cancelli Limestone. They are made of $\mathrm{cm}$ - to $\mathrm{dm}$-thick beds of dark shales alternate with $\mathrm{cm}$-thick beds of fine- to medium-grained arenites showing sedimentary features as lamination and ripples (F9 facies of Mutti, 1992). The a/p ratio is $<1$. Breccia levels with $\mathrm{cm}-$ to $\mathrm{dm}$-size Nummulite-rich limestones and medium grained arenitic clasts occur.

\section{3 | Cabanaira Unit}

It is located in the SW sectors of the studied area and covers about $2 \mathrm{~km}^{2}$ (Figure 2a). From the bottom to the top, is made fossil-rich carbonate platform deposits (Figure 4f, Fort Pepin Limestone) of Middle(?) Jurassic age according to Gidon (1972). Middle Eocene (Lutetian?) Nummulite-rich limestones (Figure 4g; unconformably?) overlay the Jurassic carbonates (Figure 2b). Nummulite-rich limestones (Nummulitic Limestone) pass upward (Figure 2b) to deep-sea fan turbidites (Cima Aurusi Formation). The contact is marked by m-thick marly-limestones. Turbidite deposits are characterized by $\mathrm{cm}$-thick beds of dark shales alternating with the $\mathrm{cm}$ - to $\mathrm{dm}$-thick beds of fineto medium-grained arenites (Figure $4 \mathrm{~h}$ ) and Nummulite-rich beds. Arenitic beds show sedimentary features such as cross-stratification and laminations (F9 facies of Mutti, 1992). In the upper part of this formation, a m-sized block of limestones and Nummulite-rich limestones occur. The close stratigraphic relationships with the underlying 

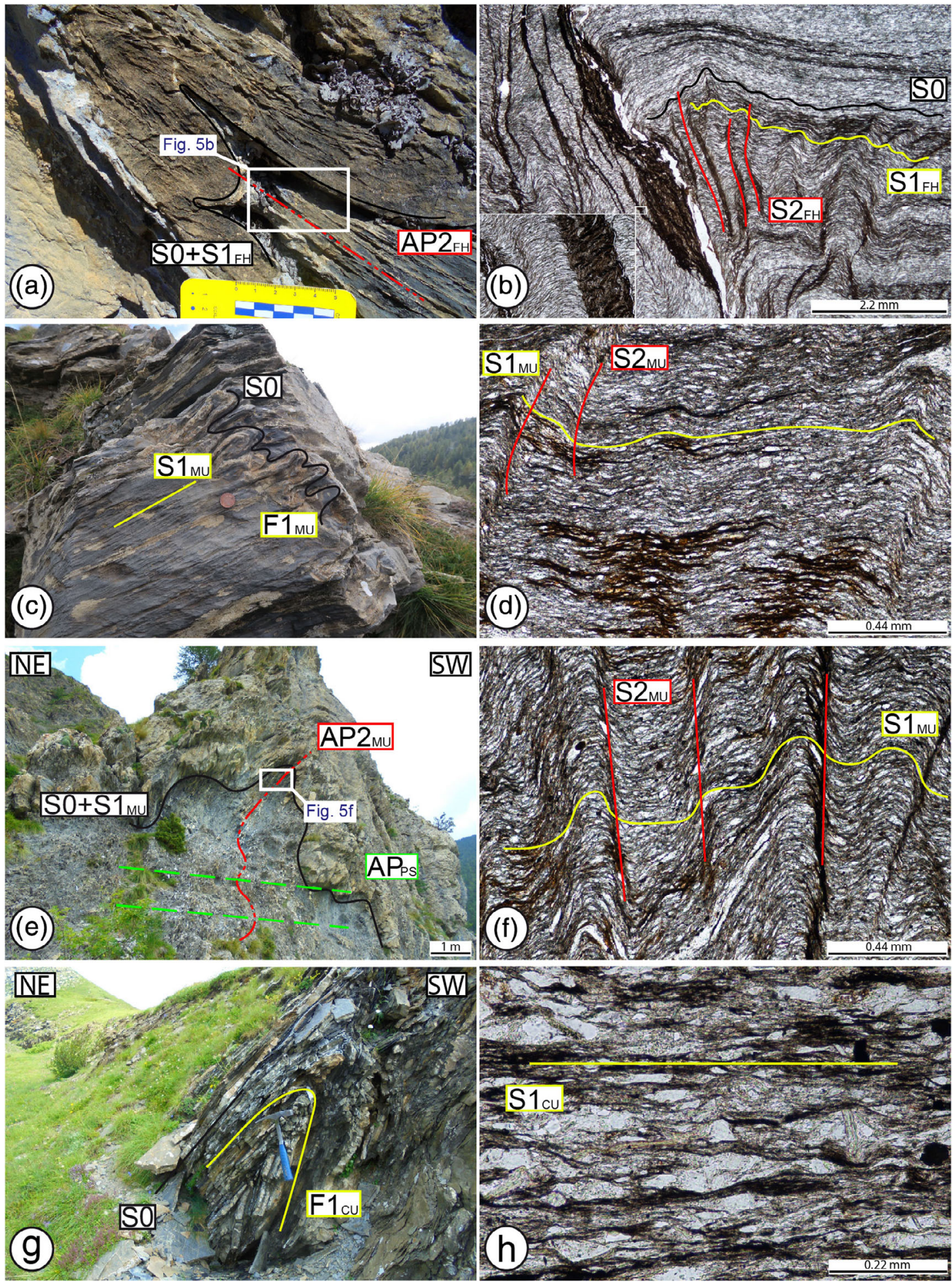

FIGURE 5 Outcrop- to micro-scale structural features of the tectonostratigraphic units. (a) $\mathrm{F} 2_{\mathrm{FH}}$ fold described by folding of $\mathrm{SO} / \mathrm{S} 1_{\mathrm{FH}}$ surface and associated $\mathrm{S} 2_{\mathrm{FH}}$ foliation in Bordighera Sandstone; the $\mathrm{AP} 2_{\mathrm{FH}}$ axial plane is indicated. Overprinting relationships are widely confirmed at microscopic scale (b). The SO is highlighted by alternating carbonate-rich and siliciclastic-rich (dominantly phyllosilicates) layers. Close-up on the left angle of (b) highlighted the $S 1_{\mathrm{FH}}$ foliation. (c) $\mathrm{F} 1_{\mathrm{MU}}$ folds with $\mathrm{S} 1_{\mathrm{MU}}$ foliation developed in Upega Formation. (d) Microphotograph of the $\mathrm{S} 1_{\mathrm{MU}}$ foliation gently deformed by $\mathrm{S} 2_{\mathrm{MU}}$ foliation. (e) $\mathrm{F} 2_{\mathrm{MU}}$ fold in Upega Formation deformed by axial planes (AP $\mathrm{PS}_{\mathrm{PS}}$ related to post-stacking fold system; the $\mathrm{AP} 2_{\mathrm{MU}}$ axial plane is indicated. (f) Microphotograph showing the relationships between $\mathrm{S} 2_{\mathrm{MU}}$ and $\mathrm{S} 1_{\mathrm{MU}}$ foliations in $\mathrm{F} 2_{\mathrm{MU}}$ fold hinge zone (white box in e). (g) F1 $1_{\mathrm{Cu}}$ fold in Cima Aurusi Formation. (h) Microphotograph showing $\mathrm{S} 1_{\mathrm{CU}}$ foliation developed in Cima Aurusi Formation [Colour figure can be viewed at wileyonlinelibrary.com] 
Nummulitic Limestone suggest a Middle Eocene age according to Gidon (1972)

\section{6 | DEFORMATION HISTORY OF THE TECTONOSTRATIGRAPHIC UNITS}

\section{1 | Pre-stacking structures}

\subsection{1 | Helminthoid Flysch Unit}

Two deformations phases named $\mathrm{D} 1_{\mathrm{FH}}$ and $\mathrm{D} 2_{\mathrm{FH}}$ have been documented in the Helminthoid Flysch Unit. They are well-developed in the fine-grained rocks (the marly limestones of Bordighera Sandstone and shales of San Bartolomeo Formation). The $\mathrm{D} 1_{\mathrm{FH}}$ signature is a pervasive $\mathrm{S} 1_{\mathrm{FH}}$ foliation, parallel or at a very low-angle to the bedding ( $\mathrm{S} 0$, Figure $5 \mathrm{a}, \mathrm{b})$. We could not identify fold systems related to the $\mathrm{D} 1_{\mathrm{FH}}$ phase. $S 1_{F H}$ foliation is more pervasive in the hinge zones of $F 2_{F H}$ folds (Figure $5 \mathrm{~b}$ ). At the microscale, $\mathrm{S} 1_{\mathrm{FH}}$ foliation is often preserved in $\mathrm{D} 2_{\mathrm{FH}}$ microlithons as a slaty cleavage (Passchier \& Trouw, 1996) marked by elongated grains of calcite, quartz, albite, and phyllosilicates of sedimentary origin (Figure $5 b$ ). The main grain-scale deformation mechanism appears to have been assisted by pressure solution; passive rotation is also evident in phyllosilicates. $\mathrm{S} 1_{\mathrm{FH}}$ foliation trends NW-SE trend with dip both towards west or east at various angles (Figure 6).

Large-scale fold structures are dominantly related to the $\mathrm{D} 22_{\mathrm{FH}}$ deformation phase; they are mainly southwestward-verging $\mathrm{F} 2 \mathrm{FH}_{\mathrm{FH}}$ fold system (Figure 5a), developed from micro- to map-scale, showing parallel geometry (class 1B of Ramsay, 1967), generally with low interlimb angles and rounded hinge zones (Figure $5 \mathrm{a}$ ). $\mathrm{F} 2 \mathrm{FH}_{\mathrm{FH}}$ fold with a roughly similar geometry are rarely present at the outcrop-scale only. The $\mathrm{F}_{\mathrm{FH}}$ folds show a $S 2_{\mathrm{FH}}$ foliation parallel or sub-parallel to the $\mathrm{F} 2_{\mathrm{FH}}$ fold axial planes $\left(\mathrm{AP} 2 \mathrm{FH}_{\mathrm{FH}}\right.$ ) and it represents the main foliation at the outcrop-scale (Figure $5 \mathrm{a}$ ). Along the limbs of the $\mathrm{F} 2_{\mathrm{FH}}$ folds, the $\mathrm{S} 2_{\mathrm{FH}}$ foliation is a continuous foliation, whereas in the hinge zone of the $\mathrm{F} 2 \mathrm{FH}_{\mathrm{FH}}$ folds is a zonal to discrete crenulation cleavage. At the microscopic-scale (Figure $5 \mathrm{~b}$ ), the mineralogical support of the $\mathrm{S} 2_{\mathrm{FH}}$ foliation are opaque (oxides?) and phyllosilicates without significant metamorphic recrystallization (Figure 5b). The main foliation-forming mechanism appears to be pressure solution. The stereo plots (Figure 6) show that $\mathrm{S} 2_{\mathrm{FH}}$ and $\mathrm{AP} 2_{\mathrm{FH}}$ are NW-SE trending and plunge both towards $\mathrm{W}$ or the $\mathrm{E}$ (Figure 6). $\mathrm{A} 22_{\mathrm{FH}}$ axes shows a NW-SE trend and plunge both towards NW and towards SE with angles ranging from $10^{\circ}$ to $35^{\circ}$.

\subsection{2 | Marguareis Unit}

Three deformation phases (hereafter named D1 $1_{\mathrm{MU}}, \mathrm{D} 2_{\mathrm{MU}}, \mathrm{D} 3_{\mathrm{MU}}$ ) are evident at any scale in this unit, in accord with Brizio et al. (1983). $D 1_{M U}$ phase is represented by a pervasive $S 1_{M U}$ foliation showing WNW-ESE trend with variable dip both towards the West and towards the East. At the microscope scale (Figure $5 \mathrm{~d}$ ), $\mathrm{S} 1_{\mathrm{MU}}$ foliation is a slaty cleavage supported by white mica, calcite, and quartz grains, often with

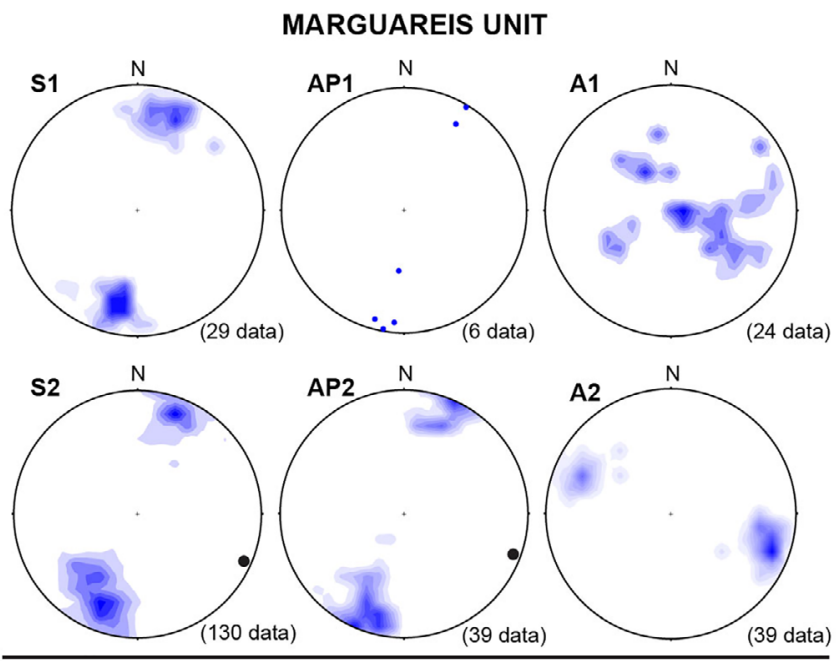

HELMINTHOID FLYSCH UNIT
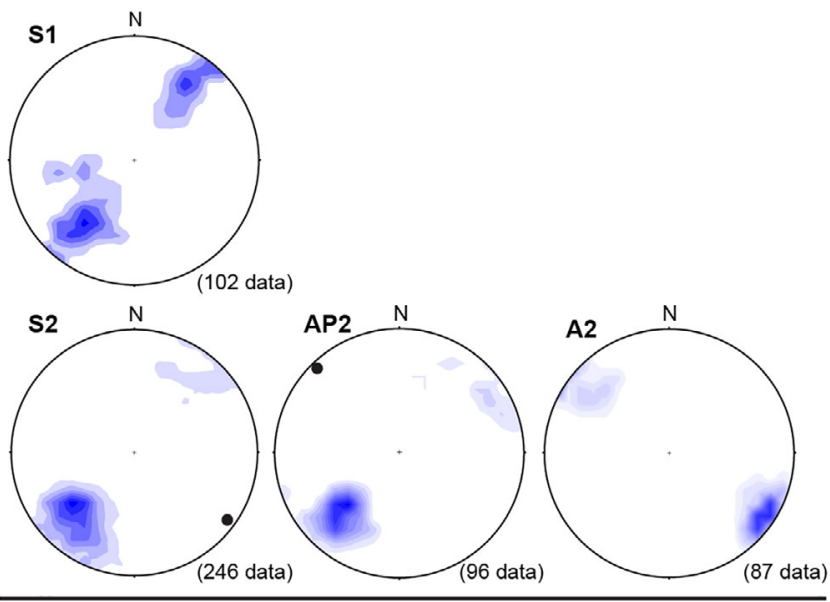

CABANAIRA UNIT

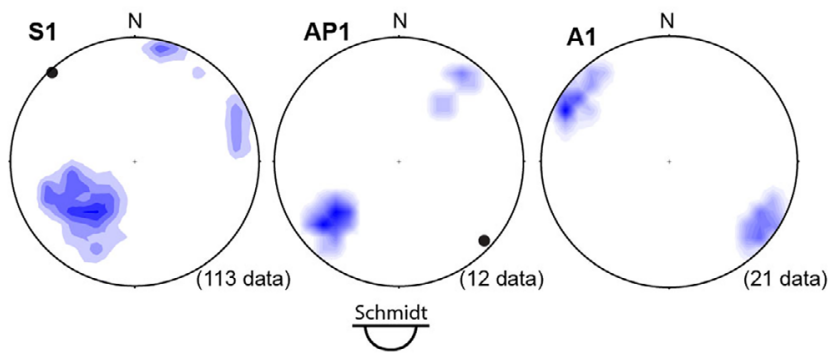

FIGURE 6 Stereographic projection of the main structural features of the tectonostratigraphic units. Dark circles indicate the main orientation of the post-stacking fold axes. Counting interval: 2, significance level: 3 [Colour figure can be viewed at wileyonlinelibrary.com]

marked shape-preferred orientation. Pressure solution appears to be the main deformation mechanism, accompanied by granular passive rotation. $\mathrm{S} 1_{\mathrm{MU}}$ foliation is parallel to the $\mathrm{F} 1_{\mathrm{MU}}$ fold axial planes (AP1 $1_{\mathrm{MU}}$; Figure $5 \mathrm{c}$ ). $\mathrm{F} 1_{\mathrm{MU}}$ folds show rounded hinge zones, scattered fold axes and pronounced similar geometry (class $1 \mathrm{C}$ of Ramsay, 1967) and they are clearly dominant over the micro- to map-scale. Moving from east to west, the attitude of the $A P 1_{M U}$ and $S 1_{M U}$ changes (Figure $2 a$ ) from a north-eastward gentle to sub-horizontal dip. 


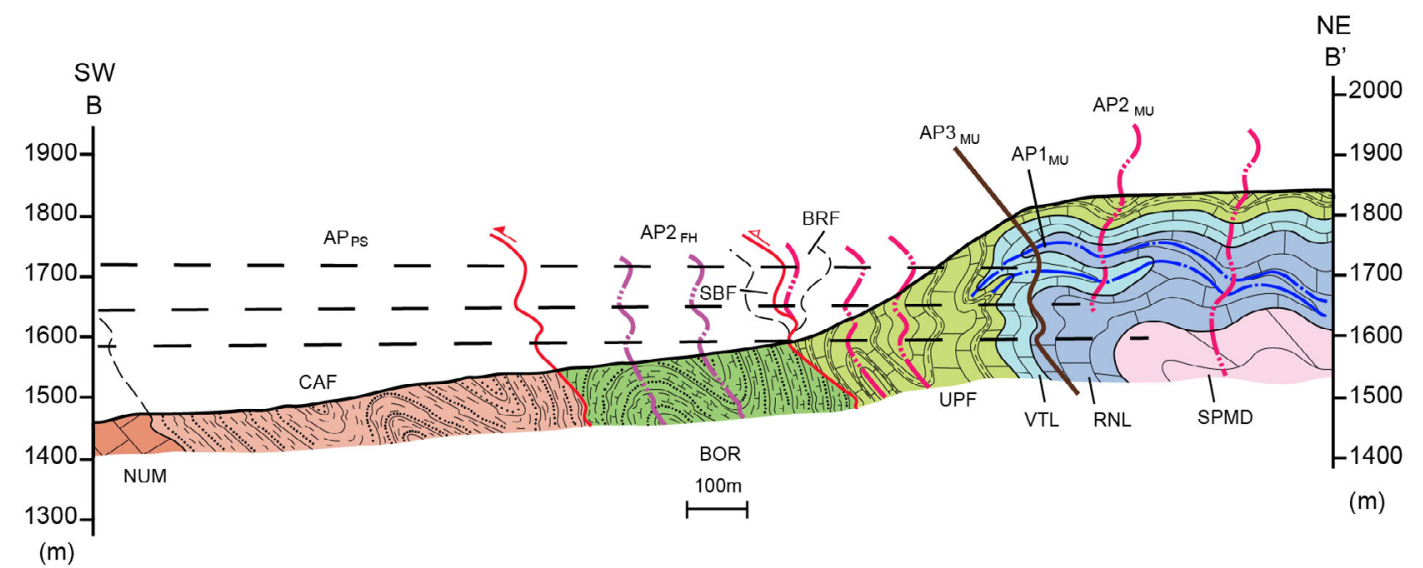

FIGURE 7 Geological cross-section along the B-B' trace in Figure 2a showing the knee-shaped F3 ${ }_{M U}$ fold with northeastward-dipping axial plane (brown line) and its relationships with the previous deformations affecting the Marguareis Unit. BRF: Boaria Formation; MCL; UPF: Upega Formation; VTL: Val Tanarello Limestone; RNL: Rio di Nava Limestone; SPDM: San Pietro dei Monti Dolostone; BOR: Bordighera Sandstone; SBF: San Bartolomeo Formation; CAF: Cima Aurusi Formation; NUM: Nummulitic Limestone. AP1 $1_{\mathrm{MU}}$ : axial plane of the F1 $1_{\mathrm{MU}}$ folds; $\mathrm{AP} 2_{\mathrm{MU}}$ : axial plane of the $\mathrm{F} 2_{\mathrm{MU}}$ folds; $\mathrm{AP} 3_{\mathrm{MU}}$ : axial plane of the $\mathrm{F} 3_{\mathrm{MU}}$ folds; $\mathrm{AP} 2_{\mathrm{FH}}$ : axial plane of the $\mathrm{F} 2_{\mathrm{FH}}$ folds; $\mathrm{AP}_{\mathrm{PS}}$ : axial plane of post-stacking folds [Colour figure can be viewed at wileyonlinelibrary.com]
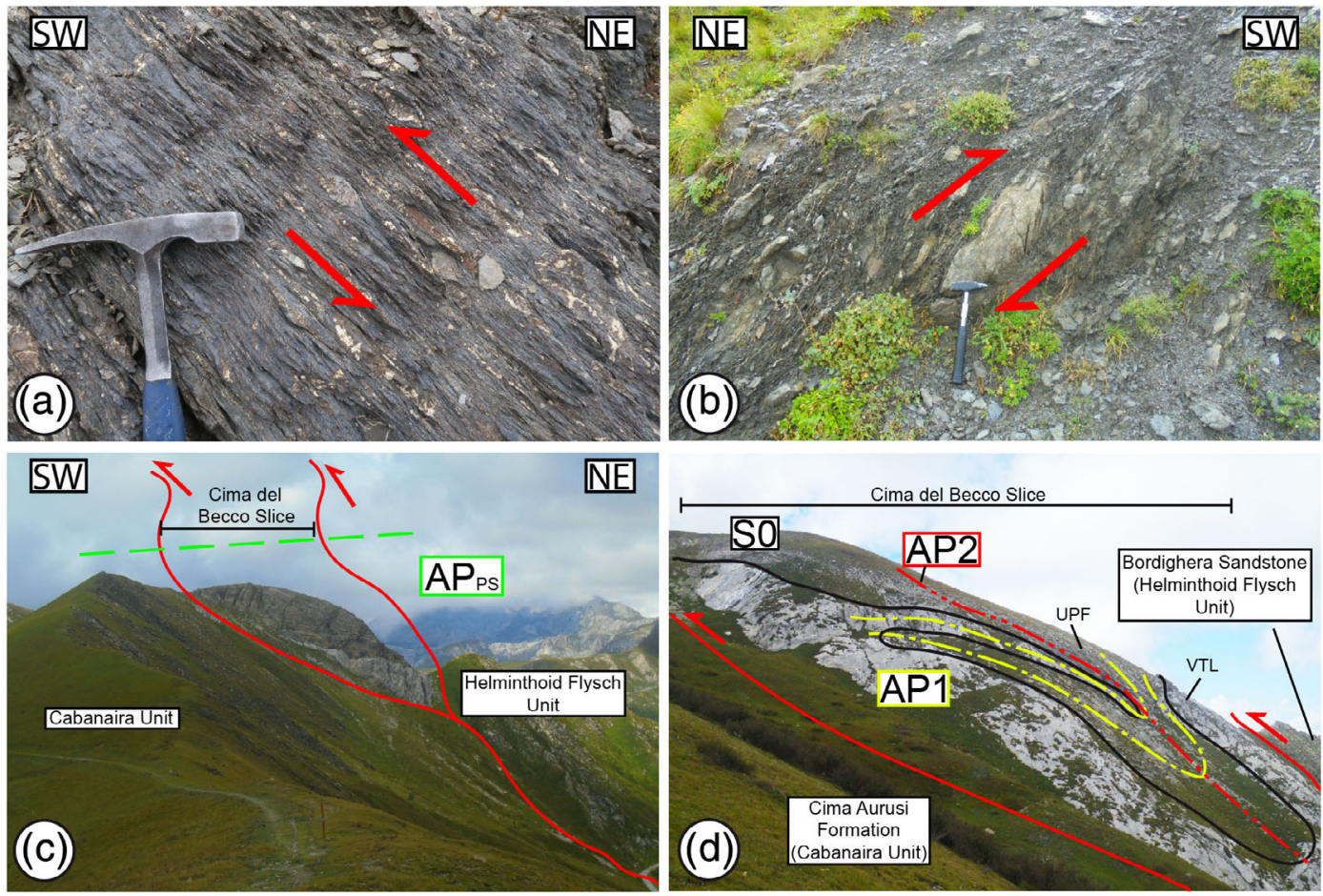

FIGURE 8 (a) Kinematic indicators of the uppermost (a) and lowermost (b) unit-bounding shear zones (for the location of the outcrops see Figure 2a). (c) Panoramic view of the Cima del Becco Slice (blue box in A-A' geological cross-section of Figure 2c. (d) Superposition relationships of two fold systems within the Cima del Becco Slice [Colour figure can be viewed at wileyonlinelibrary.com]

$\mathrm{D} 2_{\mathrm{MU}}$ phase is testified by a spaced to pervasive S2 $\mathrm{MU}$ foliation, particularly diffused in marly layers of Upega Formation and in pelitic layers of Boaria Formation, displaying well differentiated mineral-scale layering and parallel or sub-parallel to the $F 2_{\mathrm{MU}}$ folds axial planes (AP2 $2_{M U}$; Figure 5e). At the microscope scale (Figure 5f), $\mathrm{S} 2_{\mathrm{MU}}$ differenced foliation is a crenulation cleavage. It is outlined by pressure solution surfaces with rare syn-kinematic white micas (Figure 5f). F2 2 Mu folds develop from micro- to map-scale and show tight interlimb angles, rounded hinge zone with parallel to similar geometry (class $1 \mathrm{C}$ of Ramsay, 1967). $\mathrm{AP} 2_{\mathrm{MU}}$ and $\mathrm{S} 2_{\mathrm{MU}}$ foliation shows a NW-SE trend dipping both toward the west and towards the east (Figure 6). Moving from northeast to the southwest, the 
attitude of the $\mathrm{S} 2 \mathrm{MU}$ and $\mathrm{AP} 2_{\mathrm{MU}}$ changes from westward- to eastward- dipping (Figure 2b). The $\mathrm{A} 2 \mathrm{MU}$ axes shows a NW-SE trend with plunge ranging from $10^{\circ}$ to $40^{\circ}$ both towards the NW and towards the SE.

$\mathrm{D} 3_{\mathrm{MU}}$ phase is testified by a kilometre-scale knee-shaped $\mathrm{F} 3_{\mathrm{MU}}$ folds with NW-SE trending $\mathrm{A} 3_{\mathrm{MU}}$ axes and eastward-dipping axial plane (Figure 7). An S $3_{M U}$ differenced foliation occurs only locally and preferentially in lithotypes originally clay-rich. The vertical limb of F3 $3_{\mathrm{MU}}$ fold is located near to the contact between Marguareis Unit and underlying Helminthoid Flysch Unit (Figures 2a and 7).

\subsection{3 | Cabanaira Unit}

One deformation phase (named $\mathrm{D} 1_{\mathrm{CU}}$ ) has been recognized in this unit. $\mathrm{D} 1_{\mathrm{Cu}}$ phase is testified by a spaced (in more competent rocks) to pervasive (in less competent rocks) $\mathrm{S} 1_{\mathrm{CU}}$ foliation parallel or subparallel to the SO bedding. $\mathrm{S}_{\mathrm{CU}}$ foliation is well preserved in the hinges zone of the $\mathrm{F} 1_{\mathrm{CU}}$ folds (Figure $5 \mathrm{~g}$ ). At the microscopic scale (Figure $5 \mathrm{~h}$ ), $\mathrm{S} 1_{\mathrm{Cu}}$ foliation is a slaty cleavage. Its mineralogical support comprises elongated quartz and (detrital?) feldspar grains and white micas. Lenticular domains of quartz and calcite aggregates also occur. $\mathrm{S} 1_{\mathrm{CU}}$ is parallel or sub-parallel to the $\mathrm{F} 1_{\mathrm{CU}}$ folds axial planes ( $\mathrm{AP} 1_{\mathrm{CU}}$ ).
F1 $1_{\mathrm{CU}}$ folds show rounded fold hinges, tight interlimb angles and fairly similar geometry (class 1B-1C of Ramsay, 1967). F1 $1_{C U}$ folds develop from micro- to map-scale and their asymmetry suggests a southwestward vergence (Figures $2 \mathrm{c}$, and 7 ). Both $\mathrm{AP} 1_{\mathrm{Cu}}$ and $\mathrm{S} 1_{\mathrm{CU}}$ foliation show a NW-SE trend and dip with ranging angles both towards to SW and towards the NE. $A 1_{C U}$ folds axes shows a NW-SE trend and plunge both towards the NW and towards the SE with angle from $20^{\circ}$ to $30^{\circ}$ (Figure 6).

\section{2 | Syn-stacking structure: Geometry and kinematics of the main shear zones}

The unit-bounding shear zones acquired during the syn-stacking tectonics have a NW-SE trend and show a complex geometry (Figure 2a). The uppermost shear zone system separates the Marguareis Unit from the underlying Helminthoid Flysch Unit and is well exposed in the Monte Alpetta and La Perla areas (Figure 2a). It is represented by m-thick high-strain zone characterized by a foliated cataclasite (Figure 8a). Kinematic indicators pointing out top-to-SW sense of shear. The lowermost shear zone separating Helminthoid Flysch Unit from underlying Cabanaira Unit is well exposed in the Colletto Campanin area (Figure 2a). It consists of intensively foliated dm- to m-

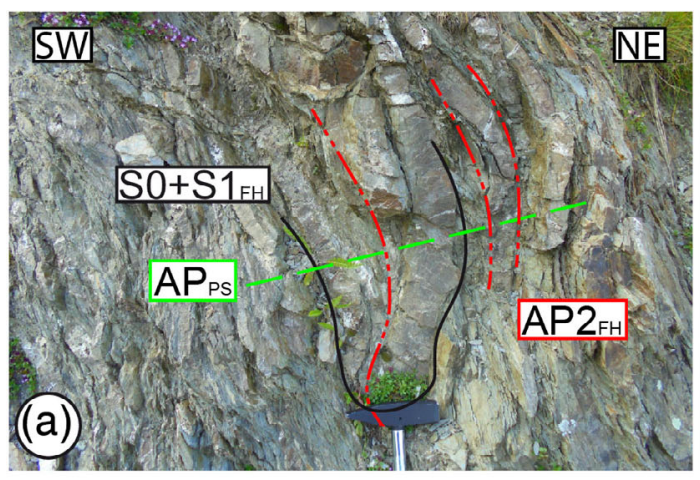

(c)

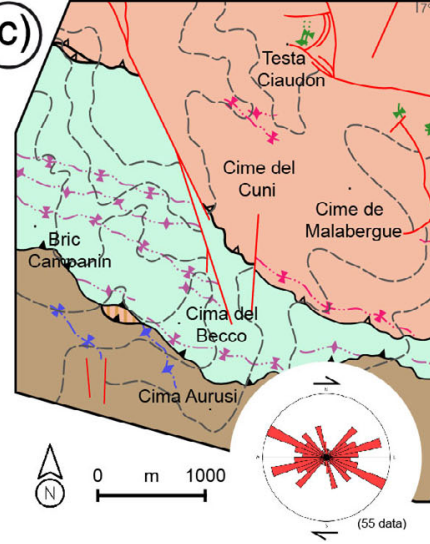

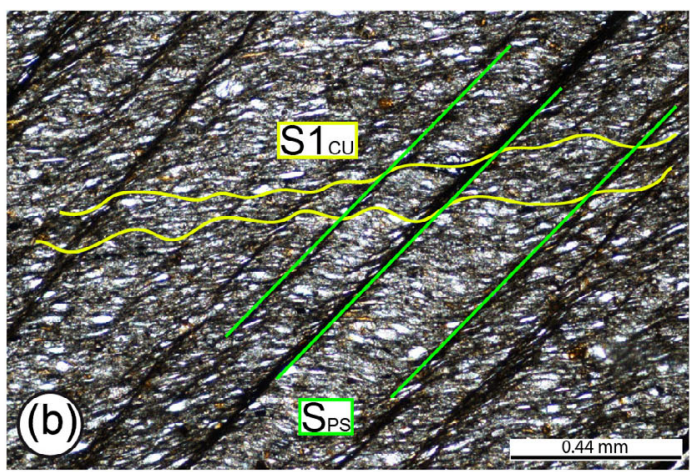

Legend

FH Helminthoid Flysch Unit

MU Marguareis Unit

BS Cima del Becco Slice

$\mathrm{CU}$ Cabanaira Unit

Symbols

*. D1mu axial plane $\leadsto$ Out-of-sequence

*. D1cu axial plane Thrust

+. D2FH axial plane - - PS fold axial plane

4.- D2mu axial plane $>$ Fault

FIGURE 9 (a) Post-stacking fold system at outcrop-scale. (b) Microphotograph of the pressure solution dark films, accreted at the expenses of the grains, visibly truncated in the lithons; the new films are associated to the post-stacking fold system. (c) Simplified tectonic sketch of the study area showing the cross-cutting relationships between post-stacking and pre-stacking structures. Statistical analysis of the fault network (rose diagram) is showed [Colour figure can be viewed at wileyonlinelibrary.com] 
thick high-strain zone with kinematic indicators which suggest a topto-SW sense of shear (Figure 8b). The unit-bounding shear zones cut the axial planes of $\mathrm{F} 1_{\mathrm{CU}}, \mathrm{F} 2_{\mathrm{FH}}, \mathrm{F} 1_{\mathrm{MU}}$, and $\mathrm{F} 2_{\mathrm{MU}}$ folds (Figure 2a) including those documented in the Cima del Becco Slice (Figure 8c,d) and they are responsible for imbrication of units. It must be highlighted that the $\mathrm{F}_{\mathrm{MU}}$ fold axial planes are not cut by these shear zones (see Figure 7).

\section{3 | Post-stacking structures}

All the structures previously described are deformed in turn by fold system (post-stacking fold system, PS) with sub-horizontal to southwestward-dipping axial planes ( $\mathrm{AP}_{\mathrm{PS}}$, Figures $2 \mathrm{c}$ and 7 ) and NW-SE trending axes plunging gently towards the southeast with angles ranging from $10^{\circ}$ to $15^{\circ}$ (Figure 6). At the outcrop-scale (Figure 9a), the grain-scale foliation is rarely observable in the less competent layers only. In thin-section, this event is highlighted by folding of the previous foliations and, sometimes, it is marked by pressure solution surfaces $\left(\mathrm{S}_{\mathrm{PS}}\right)$ without metamorphic recrystallization (Figure 9b). The superposition of these late fold systems with the previous structures forms a type- 3 interference pattern (Ramsay, 1967) from outcrop- to map-scale (Figures 2c and 7). Subsequently, sub-vertical to vertical transcurrent to normal fault network deform all the previous structures including the post-stacking fold system and the unit-bounding shear zones (Figure 9c). Kinematic indicators are rarely observed. The statistical analysis of the fault distribution (Figure 9c) highlights a well-developed Riedel system characterized by two major fault systems showing N110N120 and N50-N70 directions. Minor fault systems showing directional variability and associated with the previous major systems occur. A third fault system shows N160-N170 direction and forms a high-angle with the previous systems.

\section{7 | DISCUSSION}

\section{1 | Pre-deformation setting}

The Meso-Cenozoic successions of the Marguareis and Cabanaira Units are coherent with the palaeogeographic location in the Europe continental margin as already proposed by Decarlis et al. (2013) for the analogue units cropping out in neighbouring areas. Both the successions show a coarsening-upward trend with a transition from carbonate deposits, spanning from Triassic to Late Cretaceous (San Pietro dei Monti Dolostone, Rio di Nava Limestone, Val Tanarello Limestone, Upega Formation for the Marguareis Unit and Cima del Becco Slice, and Forte Pepin Limestone for the Cabanaira Unit), to middle Eocene slope and foredeep deposits (Madonna dei Cancelli Limestone, Boaria Formation for Marguareis Unit, and Nummulitic Limestone, Cima Aurusi Formation for Cabanaira Unit), as outlined by several authors (Decarlis et al., 2013 and reference therein). The facies association recognized in the Boaria and Cima Aurusi formations suggests a slope environment characterized by gravitational instability. The transition from carbonate platform to slope deposits suggests a foredeep-ward motion of the continental lithosphere (i.e., Europe continental margin) before its underthrusting and subsequent accretion into the Alpine orogenic wedge.

In contrast, the Helminthoid Flysch Unit reveals a different stratigraphic evolution. It consists of a Late Cretaceous turbidite succession detached from its original basement along the weak horizon corresponding to the varicoloured shales of San Bartolomeo Formation. The stratigraphic features recognized in Bordighera Sandstone suggest a depositional environment dominated by deep sea turbidites arranged as a lobe system dominated by medium- to coarse-grained deposits. The lack of syn-sedimentary deformation as slumps, intraformational breccias and the absence of chaotic deposits at the top of succession indicate the absence of gravitational instability of the depositional interface. These observations suggest a different evolution for the succession of the Helminthoid Flysch Unit respect to those of the Marguareis and Cabanaira units. Marroni, Meneghini, and Pandolfi (2010) regarded Helminthoid Flysch Units of the Northern Apennines (i.e., External Ligurian Units) as sedimentary cover of an ocean-continent transition located near to Adria Plate (for a discussion see Marroni et al., 2010; Marroni, Meneghini, \& Pandolfi, 2017). Differently, Mueller et al. (2018) regarded San RemoMonte Saccarello Unit of Western Ligurian Alps (cf. Helminthoid Flysch Unit) as an oceanic-derived unit. These authors proposed a Late Cretaceous palaeogeography where the succession of the Helminthoid Flysch Unit was located onto the oceanic lithosphere, close to the Europe margin, that is the palaeogeographic location proposed for the Internal Ligurian Units (Marroni et al., 2017 and quoted references). The stratigraphy of all these tectonic units is characterized by a Jurassic oceanic basement including the radiolaria-bearing Chert Fm., an Early Cretaceous oceanic sedimentary cover (cf. Calpionella Limestone and Palombini Shale), the Late Cretaceous turbidite sequence (cf. Val Lavagna Shale and Gottero Sandstone) and finally the Late Cretaceous-Early Palaeocene trench-slope chaotic deposits (cf. Bocco Shale and correlated formations, Marroni \& Pandolfi, 2001) that represent the last deposit before the subduction of the oceanic lithosphere and its involvement in the Alpine accretionary wedge.

The comparison between San Remo-Monte Saccarello Unit and the Internal Ligurian Units seems to be weak mainly due to the absence of the Jurassic oceanic sequence and a Late Jurassic-Early Cretaceous oceanic sedimentary cover (cf. Chert Fm. and Calpionella Limestone) and also for the lack of the Late Cretaceous-Early Palaeocene trench-slope deposits.

On the contrary, the Helminthoid Flysch Unit shows a stratigraphic sequence corresponding to those well known in the tectonic units interpreted as External Ligurian Units that were deposited in the ocean-continent transition between the Ligure-Piemontese Ocean and the Adria Plate margin (Marroni \& Pandolfi, 2001, cf. Cassio, Caio, Antola units).

In this frame, we suggest for the Helminthoid Flysch Unit of the Marguareis area a palaeogeographic location similar to External Ligurian Units. 


\section{2 | Tectonic interpretations of the pre-stacking deformations}

The tectonostratigraphic units that have been studied record different pre-stacking deformation events. These events are represented in the Marguareis Unit by the first two deformation phases, named D1 $\mathrm{MU}$ and D2 $\mathrm{MU}$ (cf. Brizio et al., 1983). Based on results of their structural analysis, which is confirmed by our observations, several authors (Carminati, 2001; Seno, 1992; Vanossi et al., 1984) proposed that $\mathrm{D} 1_{\mathrm{MU}}$ phase developed in ductile shear zones during overall southwestward motion of the Marguareis Unit. The D2MU phase is instead associated with the regional backthrusting event (NE-direct). The metamorphic peak conditions are reached during the $\mathrm{D} 1_{\mathrm{MU}}$ phase according with the recrystallizations supported by the $\mathrm{S} 1_{\mathrm{MU}}$ foliation. The D2 $\mathrm{MU}$ phase was developed at lower $\mathrm{P}$ and $\mathrm{T}$ conditions when the Marguareis Unit started to be exhumed, as suggested by Carminati (2001). In other sectors of the Briançonnais Domain corresponding deformation phases have been documented by Menardi-Noguera (1988), Michard et al. (2004), Strzerzynski et al. (2011), and Bonini, Dallagiovanna, and Seno (2010).

In the Cabanaira Unit, only one deformation event ( $\left.\mathrm{D} 1_{\mathrm{CU}}\right)$ has been documented. $\mathrm{F} 1_{\mathrm{Cu}}$ fold system suggests, however, a southwestward tectonic transport as that detected in the Marguareis Unit. The lack of the polyphase deformation history as reconstructed in the Marguareis Unit is probably due to the prevalence of lithologies without competence contrast that, in association with the very low-grade metamorphic conditions, hampered the development of the weaker deformations. According with these observations, a pre-stacking structural evolution as recognized in the Marguareis Unit can be supposed also for the Cabanaira Unit.

According with Menardi-Noguera (1988), Michard et al. (2004), and Strzerzynski et al. (2011), the pre-stacking deformation history recognized in Marguareis and Cabanaira Units can be interpreted as the result of the involvement in the subduction of the thinned Europe continental margin that experienced underthrusting, accretion to the orogenic wedge and later exhumation. The result of this geodynamic history is not only the deformation and metamorphism of these units but also the thrusting of the Marguareis Unit, including the Cima del Becco slice, onto the Cabanaira Unit. It must be underlined that the pre-stacking deformation history of Marguareis and Cabanaira Units, including their exhumation at shallow structural level, pre-dates the coupling with the Helminthoid Flysch Unit (Figure 10c).

The ages of these deformations are unfortunately poorly constrained. The middle Eocene age of the Flysch Noir (Lanteaume, 1968 cf. Boaria Formation in this article) places a lower boundary for the age of metamorphism and related deformations. In fact, Michard et al. (2004) proposed a post-Bartonian age (38 Ma) for the syn-metamorphic main deformation phase. Recently, Strzerzynski et al. (2011) estimated 45-37 Ma for the metamorphic peak pressure achieved during continental subduction of units from Briançonnais Domain. This age is coherent with geochronological data obtained by Monié (1990) from the metamorphic white micas (37 Ma). The exhumation of the Briançonnais units is regarded as accomplished between 37 and $31 \mathrm{Ma}$ (Michard et al., 2004; Strzerzynski et al., 2011). We propose a similar age-range for the tectonic evolution of the Marguareis Unit. Based on the middle Eocene age of the Cima Aurusi Formation (Gidon, 1972), we also propose a post middle Eocene age for $\mathrm{D} 1_{\mathrm{Cu}}$ phase.

The Helminthoid Flysch Unit is characterized by a different tectonic history. The recrystallizations along the related foliations $\mathrm{S}_{\mathrm{FH}}$, and $\mathrm{S} 2_{\mathrm{FH}}$ suggest that the entire structural evolution of this unit developed at the shallow structural levels. This evolution includes twofold systems both indicating a southwestward tectonic transport. This evolution pre-dates the coupling with the Cabanaira Unit and the Marguareis Unit (Figure 10a) as suggested by the cross-cutting relationships between the unit-bounding shear zones and the $\mathrm{D} 1_{\mathrm{FH}}$, and $\mathrm{D} 2_{\mathrm{FH}}$ two fold systems.

\section{3 | Constraints for the syn-stacking structural evolution}

The deformation developed during the syn-stacking tectonics are mainly represented by the unit-bounding shear zones, all characterized by southwestward sense of shear. These shear zones can be interpreted as thrusts responsible for the coupling of the units recognized in the study area. During this event, the present-day geometry of the unit stack was achieved immediately before the development of the post-stacking deformations. This stack includes the Cabanaira Unit that is thrust by the Cima del Becco Slice and the Helminthoid Flysch Unit, that in turn is thrust by the Marguareis Unit. According with the correlation between the Cima del Becco Slice and the Marguareis Unit, both derived from Briançonnais Domain, it is possible to propose a chronology for the development of the unit-bounding shear zones. This chronology includes first the development of the shear zone corresponding to thrusting of the Helminthoid Flysch Unit over the units derived from the Europe continental margin (Figure 10b), i.e. the Cabanaira Unit and the couple Cima del Becco Slice and Marguareis Unit, and then the development of a later shear zone corresponding to an out-of-sequence thrust today recognized between the Marguareis Unit and the Helminthoid Flysch Unit (Figure 10b). In this reconstruction, the out-of-sequence thrust can be interpreted as responsible for the $\mathrm{F} 3_{\mathrm{MU}}$ knee-shaped mega-fold recognized in the Marguareis Unit (Figure 10b). Taking in account, the age proposed for the pre-stacking structure (middle Eocene-Late Eocene), we propose that the syn-stacking tectonics developed in the Late Eocene-Early Oligocene age in accordance with the age yielded by Maino et al. (2015) for the thrusting of the Helminthoid Flysch Unit onto the Europe-derived continental units.

In the Embrunais-Ubaye transect (central sector of the Western Alps), Merle (1982) and Merle and Brun (1984) described similar geometrical relationships between the Helminthoid Flysch (nappe du Flysch à Helminthoïdes of Kerckhove, 1969) and the Briançonnais Units. In addition, also the order of stacking of the different tectonic units is similar to what we documented in the Marguareis Massif. In fact, in the Embrunais-Ubaye area the Helminthoid Flysch unit of this area are first thrust onto the already exhumed Briançonnais Units and, then, thrust by the latter by an out-of-sequence thrust. In the geological section 
FIGURE 10 Sketch illustrating the tectonic evolution of the units documented in the study area from middle Eocene to Late Eocene onward. (a) Pre-stacking structures developed in Briançonnais Units, after their underthrusting, accretion and exhumation into the Alpine orogenic wedge, and in the Helminthoid Flysch Unit. (b) Synstacking structures: thrusting of the Helminthoid Flysch Unit onto Briançonnais Units; later on, the out-ofsequence thrust of Marguareis Unit onto Helminthoid Flysch Unit modified the previous structural setting with development of D3 fold in Marguareis Unit. (c) Post-stacking structures: poststacking fold system and subsequent transtensional fault system. Arrows: black full arrows indicate the kinematics of the shear zone at the bottom of the Helminthoid Flysch Unit and Cima del Becco Slice; empty black arrow indicates the out-of-sequence thrust of the Marguareis Unit onto Helminthoid Flysch Unit, Cima del Becco Slice and Cabanaira Unit [Colour figure can be viewed at wileyonlinelibrary.com] (a)

Post-stacking

Early Oligocene onward

DEFORMATION EVENTS

The whole tectonic stack is deformed by post-stacking folds and subsequent transtensional fault system.
SW

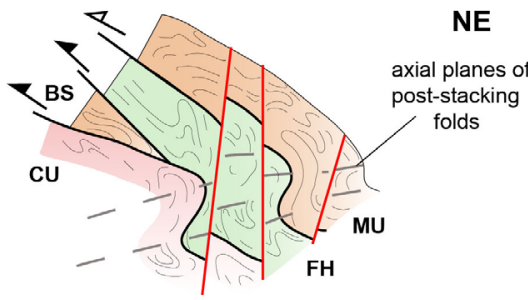

(b)

Syn-stacking

Late Eocene - Early Oligocene
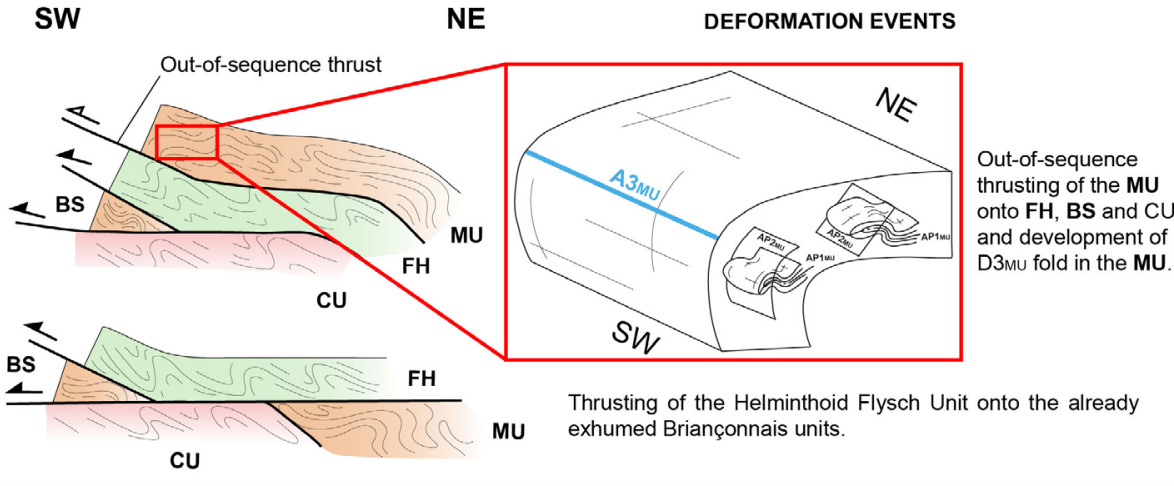

(c)

Pre-stacking

middle Eocene - Late Eocene

SW

NE
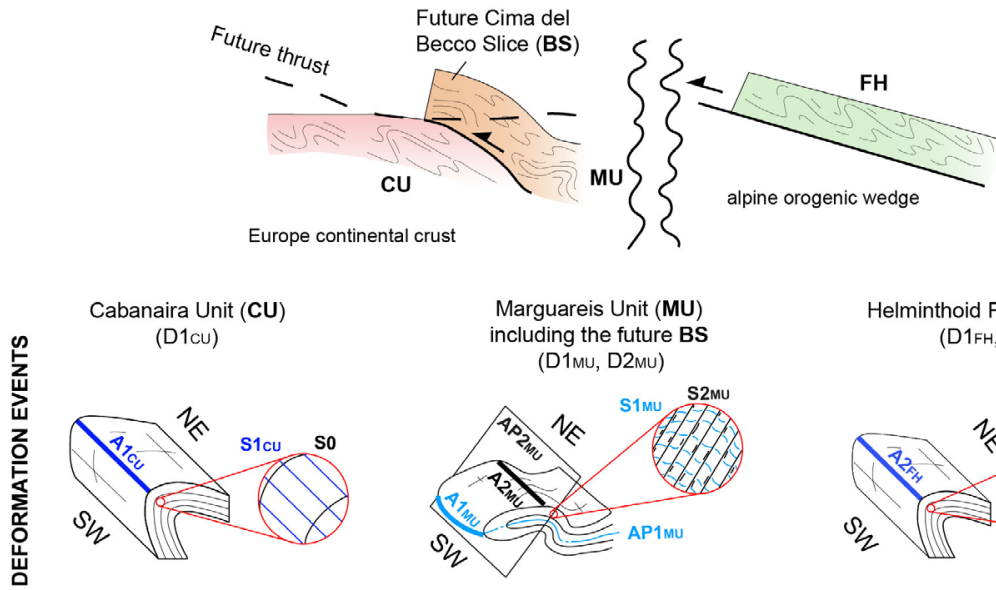

Helminthoid Flysch Unit (FH) (D1FH, D2FH)

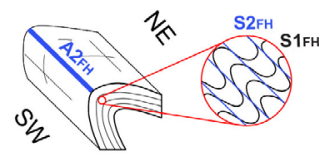

provided by Merle (1982) and Merle and Brun (1984), the Helminthoidtype Flysch unit occurs at the base and at the top of the Briançonnais Units. This picture is coherent with an uppermost position of Helminthoid Flysch Unit in the tectonic pile, as recognized in the external sector of the Western Alps (cf. Escher et al., 1997; Merle \& Brun, 1984). Also in this sector, the uppermost position of the Helminthoid Flysch Unit is only later modified by an out-of-sequence thrust.

\section{4 $\mid$ The role of the post-stacking deformations}

The whole stack is affected by the same deformation history testified by the overprinting of the post-stacking fold system and subsequent brittle faults on the pre-stacking structures and unit-bounding shear zones (Figure 10a). The post-stacking fold system, that is, characterized by flat-lying axial planes and horizontal fold axes, can be interpreted as having originated from vertical shortening and folding of pre-existing inclined layers. This type of deformation is typical of extensional tectonics, as recognized in some areas of the Alpine belt (Froitzheim, 1992; Ratschbacher, Frisch, Neubauer, Schmid, \& Neugebauer, 1989; Wheeler \& Butler, 1994). This deformation, which occurs at very shallow level owing the lacking of associated synkinematic recrystallization, probably represents the last stage of the exhumation for the studied stack of tectonic units.

The last tectonic event is represented by a transtensional fault system that cut at high angle all the previous structures and only 
locally juxtapose different tectonic units. Referring to theoretical model of transtensional tectonics (Dooley \& Schreurs, 2012; Naylor, Mandl, \& Sijpesteijn, 1986), the geometrical pattern of the faults belonging to three systems depicts a map-scale Riedel system coherent with a roughly E-W-direct dextral shear deformation. In contrast with recent interpretations (Bertok et al., 2018; d'Atri et al., 2016), these brittle deformations are not able to deeply modify the pre-existing structural setting of the study area, as detectable in the tectonic map (see Figure 2a), thus played not significant role during the structural evolution of the Marguareis Massif. The age of the post-stacking structures is scarcely constrained. Taking into account, the geochronological data provided by Michard et al. (2004) and Strzerzynski et al. (2011), an Early Oligocene age for the post-stacking structures can be proposed.

\section{CONCLUSIONS}

The collected data suggest a new picture for the structural setting of the Marguareis Massif in the frame of the tectonic evolution of the Western Alps. Stratigraphic and structural data support the distinction of two groups of tectonostratigraphic units represented, respectively, by the units derived from the Europe continental margin (i.e., Marguareis Unit, including Cima del Becco Slice, and Cabanaira Unit) and the Helminthoid Flysch Unit whose palaeogeographic location was probably along the thinned continental margin of the Adria Plate. The collected data indicates that these units acquired deformations and metamorphism at different structural levels and in different time-spans (pre-stacking deformations) before their coupling. The coupling occurred by the southwestward thrusting (syn-stacking deformations) of the Helminthoid Flysch Unit onto an already exhumed stack of the Europe-derived units (i.e., Marguareis Unit, includes Cima del Becco Slice, and Cabanaira Unit). This structural setting has been modified by an out-of-sequence thrust leading the Marguareis Unit onto the Helminthoid Flysch Unit. Subsequently, probably starting from Early Oligocene, the whole stack was deformed by the later folding and faulting (post-stacking deformations). The results of this investigation support a new interpretation of the tectonic evolution of the Marguareis Massif area whose currently setting has been mainly achieved during the pre-Oligocene pre- and synstacking tectonics without strong modifications during the poststacking tectonics that play a late and no-significant role.

\section{ACKNOWLEDGEMENTS}

The authors thank Silvio Seno and an anonymous reviewer for their patient and accurate revisions. The authors thank Chiara Frassi for her editorial job. The authors are thankful to University of Pisa (PRA project) for financial support of this project.

\section{PEER REVIEW}

The peer review history for this article is available at https://publons. com/publon/10.1002/gj.4040.

\section{DATA AVAILABILITY STATEMENT}

Data available on request from the authors.

ORCID

Edoardo Sanità (iD) https://orcid.org/0000-0002-5488-9832

\section{REFERENCES}

Barbero, E., Festa, A., Saccani, E., Catanzariti, R., \& D'Onofrio, R. (2019). Redefinition of the Ligurian Units at the Alps-Apennines junction (NW Italy) and their role in the evolution of the Ligurian accretionary wedge: Constraints from mélanges and broken formations. Journal of Geological Society, 177, 562-574.

Barfety, J. C., Lemoine, M, Mercier, D, Polino, R., Nievergelt, P., Bertrand, J., Dumont, T., Amaudric du Chaffaut, S., Pecher, A., \& Monjuvent, G. (1996). Carte Geologique de France (1/50.000), Feuille Briançon (823). Bur. de Rech. Geol. et Min., 180 p.

Bersezio, R., Barbieri, P., \& Mozzi, R. (2002). Redeposited limestones in the Upper Cretaceous succession of the Helvetic Argentera Massif at the Italy-France border. Eclogae Geologicae Helvetiae, 95, 15-30.

Bertok, C., Musso, A., d'Atri, A., Martire, C., \& Piana, F. (2018). Geology of the Colle di Tenda - Monte Marguareis area (Ligurian Alps, NW Italy). Journal of Maps, 14(2), 542-551. https://doi.org/10.1080/17445647. 2018.1500497.

Bertrand, J. M., Paquette, J. L., \& Guillot, F. (2005). Permian zircon U-Pb ages in the Gran Paradiso massif: Revisiting post-Variscan events in the Western Alps. Schweizerische Mineralogische und Petrographische Mitteilungen, 85, 15-29.

Béthoux, N., Sue, C., Paul, A., Virieux, J., Frechet, J., Thouvenot, F., \& Cattaneo, M. (2007). Local tomography and focal mechanisms in the south-western Alps: Comparison of methods and tectonic implications. Tectonophysics, 432, 1-19.

Bloch, J. P. (1958). Une coupe du Trias des Alpes ligures italiennes [A section of the Trias of the italian Ligurian Alps]. C.R. Sommairedes Sèances de la Sociètè gèologique de France, 10, 204.

Boni, A., Cerro, A., Gianotti, R., \& Vanossi, M. (1971). Note illustrative della Carta Geologica d'Italia alla scala 1:100.000, foglio Albenga-Savona (92-93). Roma.

Bonini, L., Dallagiovanna, G., \& Seno, S. (2010). The role of pre-existing faults in the structural evolution of thrust systems: Insights from the Ligurian Alps (Italy). Tectonophysics, 480, 73-87.

Bousquet, R., Oberhänsli, R., Goffé, B., Wiederkehr, M., Koller, F., Schmid, S. M., Schuster, R., Engi, M., Berger, A., \& Martinotti, G. (2008). Metamorphism of metasediments in the scale of an orogen: $A$ key to the tertiary geodynamic evolution of the Alps. In: S. Siegesmund et al. (Eds.), Tectonic aspects of the Alps-Dinaridescarpathians system (pp. 393-411). Special Publication, London: Geological Society (Vol. 298).

Brizio, F. D., Deregibus, C., Eusebio, A., Gallo, M., Gosso, G., Rattalino, E., \& Oxilia, M. (1983). Guida all'escursione: i rapporti tra la zona Brianzonese Ligure e il Flysch a Elmintoidi, Massiccio del Marguareis. (Limone Piemonte-Certosa di Pesio, 468 Cuneo, 14/15 Settembre 1983). Memorie della Societa Geologica Italiana, 26, 579-595.

Bucher, S., \& Bousquet, R. (2007). Metamorphic evolution of the Briançonnais units along the ECORS-CROP profile (Western Alps): New data on metasedimentary rocks. Swiss Journal of Geosciences, 100, 227-242.

Butler, R. W. H., Matthews, S. J., \& Parish, M. (1986). The NW external Alpine thrust belt and its implication for the geometry of the western Alpine orogen. In M. Coward, D. Dietrich, \& R. G. Park (Eds.), Alpine tectonics (Vol. 19, pp. 245-260). Special publication, London: Geological Society of London. 
Campredon, R. (1977). Les formations paléogénes des Alpes Maritimes Franco-Italiennes. Mémoires de la Société Géologique de France, 9, 199.

Carminati, E. (2001). Incremental strain analysis using two generations of syntectonic coaxial fibres: An example from the Monte Marguareis Briançonnais cover nappe (Ligurian Alps, Italy). Journal of Structural Geology, 23, 1441-1456.

Carminati, E., \& Gosso, G. (2000). Structural map of a Ligurian Briançonnais cover nappe (Conca del Carsene, Monte Marguareis, Ligurian Alps, Italy) and explanatory notes. Memoir, Geological Science Padova, 52, 93-99.

Choukroune, P., Ballévre, M., Cobbold, P., Gautier, Y., Merle, O., \& Vuichard, J. P. (1986). Deformation and motion in the Western Alpine arc. Tectonics, 7(2), 215-226.

Cobianchi, M., Di Giulio, A., Galbiati, B., \& Mosna, S. (1991). II "Complesso di base" del Flysch di San Remo nell'area di San Bartolomeo, Liguria occidentale (nota preliminare). Atti Ticinesi di Scienze della Terra, 34, 145-154.

Compagnoni, R., Elter, G., \& Lombardo, B. (1974). Eterogeneità stratigrafica del Complesso degli "Gneiss Minuti" nel massiccio cristallino del Gran Paradiso. Memorie della Societa Geologica Italiana, 13, 227-239.

Corsini, M., Ruffet, G., \& Caby, R. (2004). Alpine and late Hercynian geochronological constraints in the Argentera Massif (Western Alps). Eclogae Geologicae Helvetiae, 97, 3-15.

Coward, M. P., \& Dietrich, D. (1989). Alpine tectonics-an overview. In M. P. Coward, D. Dietrich, \& R. G. Park (Eds.), Alpine tectonics (Vol. 45, pp. 1-29). Special publication, London: Geological Society of London.

d'Atri, A., Piana, F., Barale, L., Bertok, C., \& Martire, L. (2016). Geological setting of the southern termination of Western Alps. International Journal of Earth Sciences, 105, 1831-1858.

Dal Piaz, G. V., Bistacchi, A., \& Massironi, M. (2003). Geological outline of the Alps. Episodes, 26, 175-180.

Debelmas, J., \& Kerckhove, C. (1980). II: Les Alpes franco-italiennes. Introduction à la géologiedu Sud-Est de la France. Géologie Alpine, 56, 28.

Decarlis, A., Dallagiovanna, G., Lualdi, A., Maino, M., \& Seno, S. (2013). Stratigraphic evolution in the Ligurian Alps between Variscan heritages and the Alpine Tethys opening: A review. Earth-Sciences Reviews, 125, 43-68.

Dooley, T. P., \& Schreurs, G. (2012). Analogue modelling of intraplate strike-slip tectonics: A review and new experimental results. Tectonophysics, 71, 574-575.

Escher, A., Hunziker, J. C., Marthaler, M., Masson, H., Sartori, M., \& Steck, A. (1997). Geologic framework and structural evolution of the Western Swiss-Italian Alps. In O. A. Pfiffner, P. Lehner, P. Z. Heitzmann, S. Mueller, \& A. Steck (Eds.), Deep structure of the Swiss Alps: Results from NRP 20 (pp. 205-221). Basel: Birkhäuser.

Fallot, P. (1949). Les chevauchementsintercutanés de la Roya (A.-M.). Annales Herbert-Haug, 7, 62-168.

Fallot, P., \& Faure-Muret, A. (1954). Sur le Secondaire et le Tertiaire 491 auxabordssudorientauxduMassif de l'Argentera-Mercantour (feuille de Saint Martin Vésubie, Tende et Vièveau 50.000). Bulletin de la Carte géologique de la France, 52, 283-319.

Ford, M., Duchêne, S., Gasquet, D., \& Vanderhaeghe, O. (2006). Twophase orogenic convergence in the external and internal SW Alps. Journal of the Geological Society of London, 161, 815-826.

Ford, M., Lickorish, W. H., \& Kusznir, N. J. (1999). Tertiary foreland sedimentation in the Southern Subalpine Chains, SE France: A geodynamic appraisal. Basin Research, 11, 315-336.

Frisch, W. (1979). Tectonic progradation and plate tectonic evolution ofthe Alps. Tectonophysics, 60, 121-139.

Froitzheim, N. (1992). Formation of recumbent folds during synorogenicrustal extension Austroalpine nappes, Switzerland. Geology, 20, 923-926.

Gèze, B., Lanteaume, M., Peyre, Y., \& Vernet, J. (1968). Carte Géologiqueau 1/50000 Menton-Nice, XXXVII-42-43. BRGM: Orléans.
Gidon, M. (1972). Leschainons Briançonnais et subbriançonnais de la rive gauche de la Stura entre le Val de l'Arma (province de Cuneo Italie). Géologie Alpine, 48, 87-120.

Goguel, J. (1936). Descriptiontectonique de la borduredes Alpes de la Bléoneau Var. Mémoir, Severe Carte géologique, 4, 360.

Gosso, G., Lardeaux, J. M., Zanoni, D., Volante, S., Corsini, M., Bersezio, R., ... Camera, L. (2019). Mapping the progressive geologic history at the junction of the Alpine mountain belt and the western Mediterranean ocean. Ofioliti, 44(2), 97-110.

Gratier, J. P., Mènard, G., \& Arpin, R. (1989). Strain-displacement compatibility and restoration of the Chaînes Subalpines of the western Alps. In M. Coward, D. Dietrich, \& R. G. Park (Eds.), Alpine tectonics (Vol. 45, pp. 65-81). Special Publication, London: Geological Society.

Guillaume, A. (1965). Sur la gèologie du Massif du Marguareis et de ses abords (Alpes Maritimes). Bulletin de la Société d'Histoire naturelle du Doubs, 67, 69-81.

Handy, M. R., Schmid, S. M., Bousquet, R., Kissling, E., \& Bernoulli, D. (2010). Reconciling plate-tectonic reconstructions of Alpine Tethys with the geological-geophysical record of spreading and subduction in the Alps. Earth-Science Reviews, 102, 121-158.

Kerckhove, C. (1969). La "zone duflysch" dansles nappes de l'EmbrunaisUbaye (Alpes occidentales). Géologie Alpine, 45, 5-204.

Lanteaume, M. (1957). Nouvellesdonnessur le Flysch a helminthoides de la Ligurie occidentale (Italie). Bulletin Société Gèologique de France, 7 , 115-123.

Lanteaume, M. (1962). Considérations paléogéographiques sur la patriesupposée des nappes de Flysch à Helminthoïdes des Alpes et des Apennins. Bulletin Société Géologique de France, 4, 627-643.

Lanteaume, M. (1968). Contribution à l'étudegéologique des Alpes Maritimes franco-italiennes. Mém Carte Géol France, 405 pp.

Lardeaux, J. M., Schwartz, S., Tricart, P., Paul, A., Guillot, S., Béthoux, N., \& Masson, F. (2006). A crustal-scale cross-section of the south-western Alps combining geophysical and geological imagery. Terra Nova, 18(6), 412-422.

Lavier, L. L., \& Manatschal, G. (2006). A mechanism to thin the continental lithosphere at magma-poor margins. Nature, 440, 324-328.

Le Bayon, B., \& Ballèvre, M. (2004). Field and petrological evidence for a Late Palaeozoic (Upper Carboniferous-Permian) age of the Erfaulet orthogneiss (Gran Paradiso, western Alps). CR Geoscience, 336, 1079-1089.

Maino, M., Casini, L., Ceriani, A., Decarlis, A., Di Giulio, A., Seno, S., ... Stuart, F. M. (2015). Dating shallow thrusts with zircon (U-Th)/He thermochronometry: The shear heating connection. Geology, 43, 495-498.

Maino, M., \& Seno, S. (2016). The thrust zone of the Ligurian Penninic basal contact (Monte Fronté, Ligurian Alps, Italy). Journal of Maps, 12, 341-351.

Malaroda, R. (1970). Carta Geologica del Massiccio dell'Argentera alla scala 1:50.000. Memorie della Società Geologica Italiana, 9, 557-663.

Malusà, M. G., Mosca, P., Borghi, A., Dela Pierre, F., \& Polino, R. (2002). Approccio multidisciplinare per la ricostruzione dell'assetto tettonostratigrafico e dell'evoluzione metamorfico-strutturale di un settore di catena orogenica: l'esempio dell'Alta Valle di Susa (Alpi occidentali). Memorie della Societa Geologica Italiana, 57, 249-257.

Manivit, H., \& Prud'Homme, A. (1990). Biostratigraphiedu Flysch à Helminthoïdesdes Alpes maritimes franco-italiennes. Nannofossiles de l'unité de San Remo-Monte Saccarello. Comparaison avecles Flyschs à Helminthoïdesdes Apennins. Bulletin Société Géologique de France, 8, 95-104.

Marroni, M., Meneghini, F., \& Pandolfi, L. (2010). Anatomy of the LigurePiemontese subduction system: Evidence from Late CretaceousMiddle Eocene convergent margin de- posits in the Northern Apennines, Italy. International Geology Review, 52, 1160-1192.

Marroni, M., Meneghini, F., \& Pandolfi, L. (2017). A revised subduction inception model to explain the Late Cretaceous, double-vergent 
orogen in the precollisional western Tethys: Evidence from the Northern Apennines. Tectonics, 36, 2227-2249.

Marroni, M., \& Pandolfi, L. (2001). Debris flow and slide deposits at the top of the internal liguride ophiolitic sequence, Northern Apennines, Italy: A record of frontal tectonic erosion in a fossil accretionary wedge. Island Arc, 10, 9-21.

Menardi-Noguera, A. (1988). Structural evolution of a briançonnais cover nappe, the Caprauna-Armetta unit (Ligurian Alps, Italy). Journal of Structural Geology, 10, 625-637.

Merle, O. (1982). Mise en place séquentielle de la Nappe de Parpallion (Flysch à Helmintoides, Alpes Occidentales). Comptes rendus hebdomadaires des séances de l'Académie des Sciences, 294, 603-606.

Merle, O., \& Brun, J. P. (1984). The curved translation path of the Parpaillon nappe (French Alps). Journal of Structural Geology, 6, 711-719.

Michard, A., Avigad, D., Goffé, B., \& Chopin, C. (2004). The high-pressure metamorphic front of the southwestern Alps (Ubaye-Maira transect, France, Italy). Schweizerische Mineralogische und Petrographische Mitteilungen, 84, 215-235.

Mohn, G., Manatschal, G., Müntener, O., Beltrando, M., \& Masini, E. (2010). Unravelling the interaction between tectonic and sedimentary processes during lithospheric thinning in the Alpine Tethys margins. International Journal of Earth Sciences, 99, 75-101.

Molli, G., Crispini, L., Malusà, M. G., Mosca, M. G., Piana, F., \& Federico, L. (2010). Geology of the Western Alps-Northern Apennine junction area - A regional review. Journal of Virtual Explorer, 36, 1-49.

Monié, P. (1990). Preservation of Hercynian 40Ar/39Ar ages through high-pressure low-temperature alpine metamorphism in the western alps. European Journal of Mineralogy, 2, 343-361.

Mueller, P., Langone, A., Patacci, M., \& Di Giulio, A. (2018). Detrital signatures of impending collision: The deep-water record of the Upper Cretaceous Bordighera Sandstone and its basal complex (Ligurian Alps, Italy). Sedimentary Geology, 377, 147-161.

Mueller, P., Maino, M., \& Seno, S. (2020). Progressive deformation patterns from an accretionary prism (Helminthoid Flysch, Ligurian Alps, Italy). Geosciences, 10, 26.-

Mutti, E. (1992). Turbidite sandstones (p. 275). San Donato Milanese: Istituto di Geologia, Università di Parma.

Naylor, M. A., Mandl, G., \& Sijpesteijn, C. H. K. (1986). Fault geometries in basement-induced wrench faulting under different initial stress states. Journal of Structural Geology, 8, 737-752.

Passchier, C. W., \& Trouw, R. A. J. (1996). Dilatation sites: Fibrous veins, strain shadows, strain fringes and boudins. In C. Passchier, R. Trouw \& (Eds.), Microtectonics (pp. 131-151). Berlin, Heidelberg: SpringerVerlag.

Paul, A., Cattaneo, M., Thouvenot, F., Spallarossa, D., Béthoux, N., \& Fréchet, J. (2001). A three-dimensional crustal velocity model of the southwestern Alps from local earthquake tomography. Journal of Geophysics Research, 106, 19367-19389.

Pfiffner, O. A., Erard, P. F., \& Stauble, M. (1997). Two cross sections through the Swiss Molasse basin (lines E4-E6, W1, W7-W110). In A. O. Pfiffner P. Lehner P. Heitzman S. Mueller \& A. Steck, et al. (Eds.), Deep structure of the Swiss Alps: Results from NRP 20 (pp. 64-72). Basel: Birkhäuser Verlag.

Piana, F., Battaglia, S., \& Bertok, C. (2014). Illite (KI) and chlorite (Al) "crystallinity" indices as a constraint for the evolution of the External Briançonnais Front in Western Ligurian Alps (NW Italy). Italian Journal of Geosciences, 133, 445-454.

Piana, F., Musso, A., Bertok, C., d'Atri, A., Martire, L., Perotti, E., ... Martinotti, G. (2009). New data on post-Eocene tectonic evolution of the External Ligurian Briançonnais (Western Ligurian Alps). Italian Journal of Geosciences, 128, 353-366.

Ramsay, J. G. (1967). Folding and fracturing of rocks. London, England: McGraw-Hill.
Ratschbacher, L., Frisch, W., Neubauer, F., Schmid, S. M., \& Neugebauer, J. (1989). Extension in compressional orogenic belts: The eastern Alps. Geology, 17, 404-407.

Rosenbaum, G., Lister, G. S., \& Duboz, C. (2002). Relative motions of Africa, Iberia and Europe during Alpine orogeny. Tectonophysics, 359, 117-129.

Roure, F., Howell, D. G., Guellec, S., \& Casero, P. (1990). Shallow structures induced by deep-seated thrusting. In J. L. Letouzey (Ed.), Petroleum and tectonics in mobile belts (pp. 15-30). Paris, France: Editions Technip.

Sagri, M. (1984). Litologia, stratimetria e sedimentologia delle torbiditi di piana di bacino del Flysch di San Remo (Cretaceo superiore, Liguria occidentale). Memorie della Società Geologica Italiana, 28, 577-586.

Sanchez, G., Rolland, Y., Jolivet, M., \& Brichau, S. (2011). Exhumation controlled by transcurrent tectonics: The Argentera-Mercantour massif (SW Alps). Terra Nova, 23, 116-126.

Sanchez, G., Rolland, Y., Schreiber, D., Giannerini, G., Corsini, M., \& Lardeaux, J. M. (2010). The active fault system in of SW Alps. Journal of Geodynamics, 49, 296-302. https://doi.org/10.1013/j.jog.2009. 11.009.

Schmid, S. M., Fügenschuh, B., Kissling, E., \& Schuster, R. (2004). Tectonic map and overall architecture of the Alpine orogen. Eclogae Geologicae Helvetiae, 97, 93-117.

Schmid, S. M., \& Kissling, E. (2000). The arc of the Western Alps in the light of geophysical data on deep crustal structure. Tectonics, 19, 62-85.

Schreiber, D., Lardeaux, J. M., Martelet, G., Courrioux, G., \& Guillen, A. (2010). 3-D modelling of Alpine Mohos in Southwestern Alps. Geophys. J. Int., 180, 961-975.

Seno, S. (1992). Finite strain and deformation within the Briançonnais Castelvecchio-Cerisola nappe of the Ligurian Alps, Italy. Journal of Structural Geology, 14, 825-838.

Seno, S., Dallagiovanna, G., \& Vanossi, M. (2005). A kinematic evolutionary model for the Penninic sector of the central Ligurian Alps. International Journal of Earth Sciences, 94, 114-129.

Siddans, A. (1979). Arcuate fold patterns in the subalpine chains of Southeast France. Journal of Structural Geology, 1, 117-126.

Stampfli, G. M. (1993). The Brianconnais, exotic terrane in the Alps? Eclogae Geologicae Helvetiae, 86, 1-45.

Stampfli, G. M., Borel, G. D., Cavazza, W., Mosar, J., \& Ziegler, P. A. (2001). Palaeotectonic and palaeogeographic evolution of the western Tethys and Peri Tethyan domain (IGCP Project 369). Episodes, 24, 222-228.

Strzerzynski, P., Guillot, S., Leloup, P. H., Arnaud, N., Vidal, O., Ledru, P., ... Darmendrail, X. (2011). Tectono-metamorphic evolution of the Briançonnais zone (Modane Aussois and Southern Vanoise units, Lyon Turin transect, western Alps). Journal of Geodynamics, 56-57, 55-75.

Tardy, M., Deville, E., Fudral, S., Guellec, S., Ménard, G., Thouvenot, F., \& Vialon, P. (1990). Interprétation des données du profil de sismiqueré flexion profonde ECORS-CROP Alpes entre le front pennique et la Ligneinsu Brienne. In P. Heitzman, F. Roure, \& R. Polino (Eds.), Deep structures of the Alps (Vol. 156, pp. 217-226). Paris: Mémoir, Géological Society France.

Tricart, P. (1984). From passive margin to continental collision: A tectonic scenariofor the Western Alps. American Journal of Science, 284, 97-120.

Tricart, P., Schwartz, S., Sue, C., \& Lardeaux, J. M. (2004). Evidence of synextension tilting and doming during final exhumation from multi-stage faults (Queyras, Schisteslustre 's, western Alps). Journal of Structural Geology, 26, 1633-1645.

Tricart, P., Schwartz, S., Sue, C., Poupeau, G., \& Lardeaux, J. M. (2001). La dénudationtectonique de la zone ultradauphinoise et l'inversion du front briançonnais au sud-est du Pelvoux (Alpes occidentales): Unedynamiquemiocène à actuelle. Bulletin Société Géologique de France, $172,49-58$ 
Vanossi, M. (1969). La serie Brianzonese del Salto del Lupo (Liguria Occidentale): Osservazione sedimentologico-stratigrafiche. Atti Istituto Geologico Universitario di Pavia, 20, 3-16.

Vanossi, M. (1972). Rilevamento geologico ed analisi strutturale delle dorsali del M. Mongioie e del M. Cimone (Brianzonese ligure).

Vanossi, M., Cortesogno, L., Galbiati, B., Messiga, B., Piccardo, G. B., \& Vanucci, R. (1984). Geologia delle Alpi Liguri: dati, problemi, ipotesi. Memorie della Societa Geologica Italiana, 28, 5-57.

Vanossi, M., \& Gosso, G. (1983). Introduzione alla geologia del Brianzonese Ligure. Memorie della Societa Geologica Italiana, 26, 441-461.

Wheeler, J., \& Butler, R. W. H. (1994). Criteria for identifying structures related to true crustal extension in orogens. Journal of Structural Geology, 16, 1023-1027.
Wortmann, U. G., Weissert, H., Funk, H., \& Hauck, J. (2001). Alpine platekinematics revisited: The adria problem. Tectonics, 20, 134-147.

How to cite this article: Sanità E, Lardeaux JM, Marroni M, Gosso G, Pandolfi L. Structural relationships between Helminthoid Flysch and Briançonnais Units in the Marguareis Massif: A key for deciphering the finite strain pattern in the external southwestern Alps. Geological Journal. 2020;1-17. https://doi.org/10.1002/gj.4040 